\title{
Study on Sustainable Rainwater Resource Utilization-Towards Deepening of Homo Environmentics
}

\author{
Akira Hiratsuka $\left.^{*}{ }^{(}\right)$, Kenzo Wakae $^{2}$ \\ ${ }^{1}$ Environmental Humanities, Independent Scholar, Kyoto, Japan \\ ${ }^{2}$ Oriental History, Ehime University, Ehime, Japan \\ Email: *ugj4339@iris.eonet.ne.jp
}

How to cite this paper: Hiratsuka, A. and Wakae, K. (2019) Study on Sustainable Rainwater Resource Utilization-Towards Deepening of Homo Environmentics. Journal of Water Resource and Protection, 11, 491-528.

https://doi.org/10.4236/jwarp.2019.115029

Received: March 13, 2019

Accepted: May 11, 2019

Published: May 14, 2019

Copyright () 2019 by author(s) and Scientific Research Publishing Inc. This work is licensed under the Creative Commons Attribution International License (CC BY 4.0).

http://creativecommons.org/licenses/by/4.0/

\begin{abstract}
This paper mainly investigated the value of the rainwater by introducing a "Logic of Encounter" that is a new logic beyond the logos and lemma through the metaphors which compare the real rainwater to one's life. A consideration regarding sustainable rainwater resource utilization has been described and the main results are summarized in the paper.
\end{abstract}

\section{Keywords}

Logic of Encounter, Analogy, One's Life, Emergency Drinking Water, Rainwater Quality Purification

\section{Introduction}

Sustainable rainwater resource utilization is now essential to secure sustained, sound, and high-quality water in the world. Therefore, a significance to recognize the rainwater as a precious water resources value (sense of wonder) is becoming more and more important worldwide.

By the way, regarding the water issues Japanese Crown Prince Naruhito has recently published a book of compiling "Speeches on Water Issues" which are the records of talks from 1987 to 2018 [1]. In this book, he describes the "Current Status and Issues of Water in the World" taking into account the activities through United Nations Secretary-Generals' Advisory Board on Water \& Sanitation (UNSGAB). There is also an address at the symposium on "Managing Water Resources for Sustainable Development" held in Tokyo (The University of Tokyo), Japan (2014) in this book. The Crown Prince says the importance of water resource management here as follows. "I consider the theme of this sym- 
posium, 'Managing Water Resources for Sustainable Development', very relevant. In the Middle East, including Oman, water scarcity is a common phenomenon. The situation has become serious as the growth of population is rapidly on the increase. As we can recognize, the proper management of water resources is a crucial task there. The experience in Oman and its challenges in this issue are therefore of great interest to me [2]". And finally a passage entitled "Quest for Better Relations between People and Water" has been recorded as a reference.

Early in Sep. 2018, the researchers in the USA have revealed that there have been micro plastics (fibrous/particulate) which become an issue for global scale in tap water etc. from 13 countries worldwide. This is a threat to humankind who utilizes it in the world. As a result, these situations will affect a self-control in one's actions as an unexpected problem. The disaster phenomenon such as an earthquake occurs not only in Japan, but also in Nepal, China, South America and so on so far. That is, this is also a serious environmental issue which we have to consider so seriously in all countries-developed and developing on a world scale view. Incidentally, we have to know that the lifespan of the infrastructures are about 50 years in general [3]. When considering this situation in the world, we think that the water supply (safe and peaceful supply of water) should be the most important issue to be taken as a first priority one. Therefore, when considering the peaceful water supply (especially, drinking water) to people at the emergency, an active utilization of rainwater is necessary more than ever before in conjunction with the strengthening of the conventional basement of water supply. Particularly, the rainwater is a natural circulating water obtained infinitely. Considering the sustainable and peaceful drinking water supply in the near future, the approach in experimental mechanics by the utilization of natural energy will be greatly anticipated. Regarding this, we published a paper entitled "Study on Sustainable Water Resource Conservation-Toward Deepening of Homo Environmentics" early last year [4].

This paper was written as a second round that follows it. In this paper, we first introduce a "Logic of Encounter" that is a new logic beyond the logos and lemma through the metaphors which compare the real rainwater to one's life to realize the value of the rainwater as precious resources in the world. Second, the rainwater resource management to maintain the suitable society learned from Miyazawa Kenji's world view/view of life ( $\fallingdotseq$ Logic of Encounter) is stated. Third, the relationship between the sound wave and the rainwater quality purification using sound frequencies is considered based on the idea of "Logic of Encounter." Finally, a consideration regarding sustainable rainwater resource utilization has been described in the paper.

\section{Logic of Encounter一The World Allied by “Engi (縁起): Dependent Origination"}

\subsection{Outline of Logic of Encounter}

A Japanese prominent philosopher Yamauchi T. says regarding the intermediary who connects the metaxu between entity (existence) and entity (existence) in the 
following.

"The intermediary is not the 'Entity', but 'Meaning'. The unification of 'One' and 'Multiple' is achieved in the world of the meaning. - the logic that works in there is an analogia. That is not the 'logic of entity', but the 'one of expression (Logic of Koto [phenonmenon] as an action)' Therefore, the 'Logic of Golden Mean' is important to open the 'Metaxu.' The thing he has reached is the 'Logic of Analogia (null analogia) [5]." (Intent).

As one already knows, there is a word "Analogy (類比 in Japanese)" as one of the logical inferences. Distinguished philosopher Prof. Dr. Kiuchi N. says in the book entitled "Logic of Encounter (Beyond Logos and Lemma)" that the absence of the "Encounter" is a root of the crisis in the world and the "Analogy" is a very center of the "Logic of Encounter" how we explain the encounter with others [6]. He has concluded that "Logic of Encounter [Kaiko: 邂逅]" is "Logic of One's Connections [En: 縁]” (This is coincidentally called a "Thought of Engi" in Buddhism) in this book. He says that if we express the "Logic of Encounter", that is, "Logic of One's Connections", the point is the encounters with people in this earthly world. That is a Bosatsu-gyo (Practices of Bodhisattva) that leads to the Buddhahood through the others before one's very eyes, that is, "Bodhisattva." If we describe the same thing by the "Logic of Analogia" in the West, the encounter with one's neighbors means the one with an absolute being. Regarding the "Logic of One's Connections [En: 縁]", he also says, "The 'Logic of One's Connections [En: 縁]' is a theory with which we intends to realize the practice theory/ethics for appropriating to the entire world by universalizing the connections including the specialty (the very core) of the East/Japanese experience. In this sense, the 'Logic of One's Connections' can become the 'Logic of Encounter' with the truth of meaning in the core that is definitely not special oriental one." It could be possible to realize the Taichi-izm (to unify "Multiple" to "One") by using this logic.

Viewed from the standpoint mentioned above, for example, we could say that the Nichiren (日蓮, 1222-1282)'s Buddhism is an "Inclusive thinking", on the other hand, the Hōnen (法然, 1133-1212)'s, an "Exclusive thinking” [7]. Regarding the "Buddhist phrases", the author has tried a thorough comparison between the Nichiren (日蓮, 1222-1282, Nam-myoho-renge-kyo [chanting the title of the Lotus Sutra]; This-world oriented completely) and Hōnen (法然, 1133-1212, [praising the name as Amida Buddha (Namu Amida butsu)]; That world oriented completely) in this book. And he points out the difference between the two. In connection with this mentioned above, Matsui T. (Prof. Emeritus, The Univ. of Tokyo; Astrobiology) states the way of thinking (two points) in his book. That is, 1) The phase "I relate, therefore I am"; To think about something in the relation with others is nothing else but unlearning the meaning. 2) Human beings are existences who unlearn why the human beings exist in the relation with others [8].

By the way, Prof. Dr. Morita K. (Osaka Gakuin University; History of Social Thought) recently introduces a thought of Baigan Ishida (1685-1744) (a Japanese 
thinker/ethicist of the Edo era; the founder of the Sekimon-shingaku) to understand the Japanese economy and the fundamental power of Japanese companies. The Sekimon-shingaku (popularized blend of Buddhist, Shinto and Confucian ethical teachings) which was a moral philosophy peculiar to Japan was established in 1730 by Ishida B. And the author states in his book that 1) Sekimon-shingaku has had a power which surpasses every other thought in giving a meaning to a daily life. 2) Ishida B. has compared the learning such as Confucianism, Buddhism, Shintoism, Taoism and so on which were used to perceive the "Human nature" to a tool with which the craftsperson polishes the mirror [9]. However, he does not refer to the way to polish the mirror in detail. Considering the facts mentioned above, Ishida B. seems to be a Taichi-ism (to unify "Multiple" to "One")—based thinker as describing in the paper. The author also says concisely in this book that Ishida B. suggests that to begin always from the "Human nature" is the standard and the ideal stance, that is, what we should be when thinking about the economy and the management. It could be said that this expression mentioned above is almost the same as an idea in The Kalpa of Decrease of the Nichiren Buddhism. That is, in "The Lotus Sutra" it is stated that "[The doctrines that they preach...] will never be contrary to the true reality." T'ien-t'ai commented on this, saying that "no worldly affairs of life or work are ever contrary to the true reality." A person of wisdom is not one who practices Buddhism apart from worldly affairs but, rather, one who thoroughly understands the principles by which the world is governed [10].

\subsection{Dual-Aspect Monism (the Teaching of the Buddha) (= Contradiction)}

According to the teaching of the Buddha, it is important for us to realize that we have to have an attitude, that is, the going back and the forth freely between the logic (science) and the contradiction (the teaching of the Buddha), not considering the two alternative courses. It has been preached that his thought makes sense of nature [11] [12]. I think that viewed from the "sustainable society", absorbing "Situation grasping type knowledge" is of course very important, but more than that, concentrating on the help to develop "Dependent origination type wisdom" will be at the present time just the most important view (so-called Smart power-handling capability [13]) in the modern world.

\subsection{Logic of Encounter as a New Logic beyond Logos (Scientific Rationality) and Lemma (Buddhistic Rationality)}

By the way, the word "fluctuation" comes up as an important keyword in the books written by the Japanese famous scholors (1) Neuroscientist Prof. Ikegaya Y. [The Univ. of Tokyo])/(2) Physicist Prof. Oguri H. [California Institute of Technology]) [14] [15]. We think that this is an understanding that the thermal fluctuation (Biology: Ikegaya) has an overwhelmingly larger number of that than the quantum mechanical one (Physics Oguri). In short, we think it is stated that" dynamic fluctuation" is extremely important. There is a problem that the words 
are positively too different between the Biology and the Physics. However, it is said that the word" Mathematics" has made the ability with which the universe (super macro) and the elementary particle (super micro) in one's extraordinary world are described possible. However, world-famous mathematician (Prof. Emeritus, Nara Women's University) Oka K. preaches that we manage to raise one's theory starting at "zero" successfully in the world of mathematics, but the human beings have no power to create the seed itself or zero itself. The starting at 'zero"' makes it possible to proceed with human's own accord. On the other hand, "up to zero" has left nothing that one can do anymore. However, the latter one is essential [16]. Therefore, it suggests that it is very important for us (ordinary citizen) to recognize deeply that the "dynamic fluctuation ( $\fallingdotseq$ up to zero)" exists in one's basement when we do act something [17].

By the way the Fate of Civil Engineering dealing with water is just only involved in either flood or drought but not both all the time. It is very difficult to modificate the intermediate between the two or to do both well. Therefore we think it is necessary to change the "Fate-changing" in Civil Engineering too.

\subsection{Engi (Dependent Origination) Starting Point to Think about the Engi (Dependent Origination) is "Life" of Human Beings}

It is important for us to ground the Self (One's life) based on the law (Space life) forever [18]. It is said in general that the sound of $116 \mathrm{~Hz}$ is the fundamental resonance frequency in the audible range of frequency. When it becomes so, “Nam-myoho-renge-kyo (南無妙法蓮華経) with a $116 \mathrm{~Hz}$ sound” which is said to be the "root of the law" through the "Correct Law (Space life)" and "Self (Self-life)" might be able to be the fundamental sound in our life time [19]. Regarding this, Dr. Ohnishi S. (a renowned professor and director of the Philadelphia Biomedical Research Institute, USA) discusses the Buddhistic life theory through the comparison with non-linear mathematics (chaos theory) in the book [20].

\subsection{Jikkai Gogu (the Mutual Possession of the Ten Worlds) (Doctrine of the Lotus Sutra)}

The Buddha, the world-honored one, says in the chapter 2 of the Lotus Sutra that the buddhas, the world-honored ones, appear in the world for one great reason alone. That is a phrase of "Kai (Open), Ji (Teach), Go (Make Comprehend), Nyuu (Make Acquire)." First, "Kai (Open)" is to open the door of Buddha wisdom to all living beings to allow them to attain purity. Second, "Ji (Teach)" is to show the wisdom to them. Third, "Go (Make Comprehend)" is to cause them to awaken to the wisdom. Finally, "Nyuu (Make Acquire)" is to induce them to enter the path of the wisdom [21]. This expression means a radical change of view of life that opens up door of "all people to attain Buddhahood." Because it has been revealed by preaching the "Kai (Open), Ji (Teach)", Go (Make Comprehend), Nyuu (Make Acquire) that the Buddhahood is endowed with the life of all living beings, and they can open and appear it. That is, the relations between the Bukkai (Buddhahood [仏界]) and the Kyukai (nine various 
realms [九界]) were broken off with each other in Nizenkyo (various teachings before Lotus Sutra). We realized the teaching called "Jikkai Gogu (the Mutual possession of the Ten Worlds) [十界互具] (a philosophy of dignity of life)" for the first time in the Lotus Sutra (Buddha's later years' Teaching [8 years]).

The Chinese Great Teacher T'ien-t'ai (538-597) showed Jikkai Gogu (the Mutual possession of the Ten Worlds) based on the doctrine of the Lotus Sutra translated by Kumaraju (鳩摩羅什) [22]. The Ten Worlds [十界] is a general term. The life situations of all creatures into the ten kinds, that is, (1) hell, (2) hungry spirits, (3) animals, (4) Asura, (5) humans and (6) heaven, as well as the worlds of (7) voice-hearers, (8) cause-awakened ones, (9) Bosatsu and (10) the spiritual realm of Buddhahood. This is the basic view of life of Buddhism. The ten aspects of the life to be provided with a moment in the all creatures with the Ten Worlds [十界] are called the junyoze [十如是] in the Hoben-pon Chapter 2 of the Lotus Sutra. That is, Junyoze [十如是] refers to 1) a form (look) [相], 2) nature (substance) [性], 3) embodiment (somatization) [体], 4) potency (power) [力], 5) function (action) [作], 6) a first cause (direct cause) [因], 7) a secondary cause (condition or indirect relation) [縁], 8) effect (result of a first cause) [果], 9) recompense (punishment or indirect result of a secondary cause) [報], and 10) complete fundamental whole (absolute equality in nine factors from the form to the recompense) [本末究竟等]. And, it becomes one hundred realms (Jikkaigogu [十界互具], Mutual Possession of the Ten Worlds) because the ten realms share the other nine realms. In other words, the Jikkaigogu (ten realms times ten realms equals one hundred realms [十界互具]) was shown in the Lotus Sutra for the first time.

Incidentally, in Nizenkyo teachings for 72 years (various teachings before Hoke-kyo Sutra), the Jikkai [十界] was captured (fixation) as a completely individual world which was separated from each other. To overcome completely the thought, the principle of revolution (all the creatures of Jikkai [十界] can also manifest the Buddhahood and will have a possibility of attaining Buddhahood) was preached. The teaching is "Jikkaigogu [十界互具]" of the Lotus Sutra. There is a "View of Engi" in the basic theory of the Buddhism to emphasize the chain of life. This means a view of "To cause by encounter." In other words, everything in this world is related with others in direct and/or indirect ways, changing and disappearing in the relationship. This is what came from the 6) a first cause (direct cause) [因], 7) a secondary cause (condition or indirect relation) [縁], 8) effect (result of a first cause) [果], 9) recompense (punishment or indirect result of a secondary cause) [報] of Jyunyoze [十如是] mentioned above. In other words, there exists 6)a first cause (direct cause) [因] and 7) a secondary cause (condition or indirect relation) [縁 $=\mathrm{En}$ ] as touching it in all the phenomena. And, a phenomenon as a result [果(result)] occurs and along with that, various kinds of “recompense (punishment or indirect result of a secondary cause) [報(effect)] $\rightarrow$ [起 = Gi]" are subsequently left. There is a following sentence by Miyazawa K. in the book entitled "Noumin Geijyutsu Gairon Koyo (The Summary for General Theory of Farmers' Arts)"- "Personal happiness never comes until the whole 
world becomes happy" [23]. We think that this is a thought connected to the words. That is, people often say that "One has never built one's own happiness on others' misfortune." Ultimately, "If all the people do not become happy, not even one's own happiness." Regarding this, the Nichiren also says as follows in his book entitled "Rissho Ankokuron (On Establishing the Correct Teaching for the Peace of the Land.)" "If you care anything about your personal security, you should first of all pray for order and tranquillity throughout the four quarters of the land, should you not?" [24]. In addition, Spanish philosopher José Ortega y Gasset also states a similar thesis that" I am me and my environment, and if I do not save the environment I could not save me either [25]." In other words, it can be said that these words are written to bring up the establishment of a worldview based on the life feeling saying "There is no one's own happiness and safety, and not only others' misfortune and danger." This is a perspective based on the" Engi Shiso (Engi thought)" of Buddhism.

\subsection{Ichinen-Sanzen (Three Thousand Realms in a Single Moment of Life (Doctrine of the Eshō-Funi)}

As mentioned above, the ten realms [十界] times 10 (ten) realms [十界] equal 100 (one hundred) realms [十界互具(百如是)]. And then, the 100 (one hundred) realms [十界互具(百如是)] times 10(ten) factors [十如是] equal 1000 (one thousand) realms (千如是). In addition, the 1000(one thousand)realms times 3 (three) worlds [三世間: 五陰, 衆生, 国土] equal 3000(three thousand) realms (三千如是). This is called 3000(three thousand) realms [三千如是]. Since sennyoze [1000 (one thousand) realms: 千如是] exist in the three types of world [the five skandhas: 五陰, shujyo: 衆生, and kokudo: 国土] and therefore, there are three thousand [三千]. The "Ichinen-Sanzen [一念三千]" means that the three thousand realms are contained in one mind. That is to say, it means the doctrine of three thousand realms [三千如是] in a single moment [一念] of life. It is said that it has been preached by the Chinese Great Teacher T'ien-t'ai.

Esho Funi [依正不二] is a principle that human life (shoho [正報]) and its environment (eho [依報]) are closely connected to each other. It means the principle of the oneness of life and its environment. It has been preached by the Chinese Great teacher Myoraku Daishi (妙楽大師) in the “Ten Aspects of Non-duality (十不二門)” in the Hokke gengi shakusen (法華玄義釈籤). The two worlds [二世間: 五陰, 衆生] are called human life (shoho [正報]) and the other one world [一世間: 国土], its environment (eho [依報]) in the "Ichinen Sanzen [一念三千]" mentioned above, respectively. It is said that the three thousand worlds of "Esho" exist in our human life (shoho [正報]). That is, "Esho" does not mean a separated thing (Relationship of Uniqueness). The Nichiren says in the book entitled "Issho Jyobutsusho (On Attaining Buddhahood in This Lifetime)" as follows. "When one seeks the Buddhas' emancipation in the minds of ordinary beings, one finds that ordinary beings are the entities of enlightenment, and that the sufferings of birth and death are nirvana. It also states that, if the minds of living beings are impure, their land is also impure, but if 
their minds are pure, so is their land. There are not two lands, pure or impure in themselves. The difference lies solely in the good or evil of our minds" [26].

Therefore, we have led to realize through the words mentioned above that our human behaviors are immediately affecting the environment.

\section{Significance to Recognize the Value of the Rainwater as Precious Water Resources}

Recently, various natural disasters such as earthquakes, tsunami, typhoons and extreme weather (mild winter, lack of sunlight [severe cold], excessive sunlight [extreme heat] etc.) have occurred. Considering national disasters and crises such as major earthquakes in Tokyo (M7.3) and Nankai megathrust earthquake (M8) expected in the forthcoming years in Japan, we think that it is necessary to change the disasters (Karma) by the rainwater to the right direction. At all events, the real rainwater which exists nearby is a precious water resources in the world. Therefore, it is thought that the importance of utilizing the real rainwater properly at the time of disaster will probably continue to grow bigger and bigger in the future. From the perspective described above, we think the most important thing is to just "recognize" the value of the real rainwater as precious water resources in the world.

\section{Thought of "Analogy" to Induce "Sense of Wonder"}

There is a word "Analogy (類比 in Japanese)" as one of the logical inferences. Such a concept derives from the "Analogia" in Ancient Greek/Latin [5]. It seems that the way of "Analogy" was originally a way to know the Divine area by humans' rationality. Therefore, it is said that the thinking of "Analogy" is commonly used in the theology grasping the inner nature of things intuitively [6]. Distinguished philosopher Prof. Dr. Kiuchi N. says that the analogy is a very center of the "Logic of Encounter (Beyond Logos and Lemma)", that is, how we explain the encounter with other living things [6].

Before considering this we briefly propose the two ways of thinking (1) Abidatsuma (Meta-teaching) [阿毘達磨] theory as a Buddhistic approach [27] and (2) Big-bang theory as a scientific approach) to think about the "Rainwater Fostering." It is thought that (1) the former one teaches us that Nature/Universe occurs by Karman [Function of “業/宿命” (Chain of Life /Relationship)] which is invisible. On the other hand, it is explained that (2) in the latter one the $\mathrm{Na}$ ture/Universe originated sometime about 20 billion years ago from the cataclysmic explosion at extremely high density and temperature [28] [29]. From the above, the Buddhistic approach is taken to mean "there existed first an invisible Karman '業/宿命' (Chain of Life/Relationship)on considering the origin of the World." The "Rainwater Fostering (To find the value of 'chain of life/relationship"' is very important for sustainable water resource conservation in the world. Therefore, we here use the analogy (metaphor) to express Life in comparing the rainwater to it [6] [30]. 


\section{To Use Metaphor to Express Life: Comparing Rainwater to Life} [31]-[39]

The Japanese distinguished scholars say in the book [31] as follows. "It is very important to feel that 'There exists life in the rainwater.' What we want to say is to lay such a view of nature in the base of Thinking." (Intent) Also the Japanese distinguished writer says in the book [32]. "Our lives existed connecting with all other visible and invisible lives." In addition, French famous writer Antoine de Saint Exup'ery states that "Water does not have taste, color and flavor. We could not define you. One just tastes you without knowing you. Water is not so much a necessary as a life itself [33]." (Intent) And, a famous British Poet, Nobel Prize winner in Literature (1948) Thomas Stearns Eliot (1888-1965) describes the origins of the knowledge hierarchy showing an inquiry regarding the word information "Where is the Life we have lost in living?" in his book. And here he states the importance of one's way of living with the "vector of regressivity" as one's Life $>$ wisdom $>$ knowledge $>$ information [34]. In addition, all living beings including humans, other animals and trees have fundamentally been kept alive because of the rainwater (power of compassion) since the dawn of history. Recently, a rainwater reuse system for a person living in an urban area based on hunting and gathering starting from scratch has been introduced in the book. Here the author says that as the real rainwater almost becomes a fresh water two hours and one minute after the rainfall, one could drink it as a drinking water. However, he also says that boiling the rainwater to remove bacteria is more desirable than the fresh one mentioned above as a drinking-water [35].

Furthermore, Japanese Life Scientist, Dr. Fukuoka S. says in his book [36] that there is just a liquid in the cell of one's life. It means that the liquid bundled out exists outside the cell. The life of the cell exists on the boundary line between the inside and the outside of that one. However, it does not exist on the line. It takes in the information of the energy and substances sorting from the outside. And it bails the ion, the waste products and the entropy (clutter) stayed in out from the inside. There exists the essence of life in the dynamic momentary motion. The author calls it "Dynamic equilibrium." This is a one-time phenomenon. This idea resembles the teaching of the "Threefold Truth" (T'ien-t'ai philosophy) in Buddhism very closely [31]-[39]. (Intent)

\section{Thinking Environment and Natural Resources Based on "Rainwater $\fallingdotseq$ Life"}

It is said that the dynamic equilibrium is a one-time phenomenon. The scientific rationality is of course a very important view. However, if we make it the basis, there is a natural limit to apply, that is, just only physical approach (Mechanism pursuing type) is not enough to clarify the real nature. Therefore, in case of purifying the rainwater, a mutual relationship between the purification device and the environmental condition surrounding it, that is, to evaluate the processing performance from the viewpoint of environmental systems is very important. This means that we does not decide if those obtained here is optimal. Because it 
depends on the information (going in and out) of the boundary. That is, the evaluation here is a limited one: other main factors of the system, other evaluations [40]. Therefore, it is thought that if we use the frequency as a catalyst-like to purify the rainwater quality, the adaptability is large. Here, we consider an "Environment and Natural Resources" based on "Rainwater $\fallingdotseq$ Life." According to the recent book titled "Homo Deus: A Brief History of Tomorrow" written by a Historian Yuval N. Harari, it is said that a (1) "Theocentric view" of the world was the predominant one before the modern era. But, it was (2) "the anthropocentric view" of the world in the modern periodrecent times. And today, the oncoming of a trial world (3) "Data-oriented view") to evolve into Homo Deus (Man of God: Trial to bring human beings close to God) with the advances of science and technology is discussed. However, It is also described that in (3) "Data-oriented view", the (2) "the anthropocentric view" itself loses the meaning at the end of the progress and the control by Homo sapiens will be impossible. And finally, he has sounded the alarm on "Data-oriented view" doing the inquiring," Is the life really just only data processing? [41]" We propose here a thought that the "life" is the criteria of the value as a common item when we consider the above-mentioned views, that is, (1) "Theocentric view", (2) "Anthropocentric view" and (3) "Data-oriented view." We think that the thinking" Environment and Natural Resources "based on the "life" is the most important thing for the water management to support our sustainable societies in the world.

\section{Kenji Miyazawa's Literary Work and Rainwater Purification}

\subsection{Kenji Miyazawa and an Overview of the Lotus Sutra}

Japanese Nichiren scholor Dr. Matsuoka M. states as follows in his book entitled "Miyazawa Kenji to Hokekyo-Nichiren to Shinran no hazamade (Kenji Miyazawa and Lotus Sutra-Between Nichiren and Shinran) [42]." From Kenji's point of view, "Lotus Sutra" is an absolutely very tolerant teaching. That becomes a mystic world that was beyond the view of rank or superiority. The Christian faith and Amida Buddha are also truthfully "Lotus Sutra." Therefore, if one only realizes the truth of it all the conflicts between different religious sects will disappear and be understood truly between humans. Kenji would have been probably thinking as has been mentioned above.

One claims an absoluteness of one's self-faith in order to recognize the faith of others. This paradox becomes a key to read and understand the logic of Kenji's faith. By the way, there is a "Ginga Tetsudo no Yoru (The Night of the Milky Way Train)" as one of the Kenji's typical children's stories [43]. The Ginga Tetsudo (Milky Way Train) is an imaginary train that runs the outer space. A story that Giovanni (poor boy) as a main character overcomes the sadness and decides to contribute to others in the train giving the dead a lift is described in the book. Dr. Matsuoka analyses the Kenji's faith of Lotus Sutra from the three points of view. That is, 1) "Shinshu Buddhistic (the influence that he was born and raised 
in the home of Jodo Shinshu Buddhism)", 2) "Experiential (the influence of his unique nature sensibility)" and 3) "Tolerant (the religious universality-intention in the latter half of his life)" based on the six words (1) "Milky Way", (2) "Map", "Ticket", (3) "Everyone", "Together", (4) "Lonely", "Sad", "Painful", (5) "Everlasting", and (6) "Truth") coming out in the train in the book. And he states that the words (1) and (2) suggest the truth, teachings and the principal object of worship of the Lotus Sutra, respectively, and although the flexible coexistence between the individual and the whole is the Lotus Sutra-based thinking, the word (3) strengthens the positive thinking to affirm the whole: (to deny the existence of individual). And then, the word (4) evidences the superiority of Shinshu Buddhistic spirituality over the Lotus Sutra-based faith. Furthermore, the word (5) shows the struggle between the Lotus Sutra-based faith and Shinshu Buddhistic spirituality. In addition, regarding (6) the meaning is not the Lotus Sutra-based one. This have brought the Shinshu Buddhistic spirituality (close-minded freedom) such as self-deprecating tendency, reliance upon others etc. It could not be regarded as Lotus Sutra-based. This book seems to be an ethical literature that was given birth by combining the Lotus Sutra-based faith and Shinshu Buddhistic spirituality from this point of view mentioned above.

And while being exposed to the relationship between "Existence" and "Truth" in the Buddhism, he insists at the last word that the both should be freely recognized. He points out that this was in conflict with leaving the relationship broken. That is, Kenji continued to act up to the world of "Existence of Savior" (Shinshu Buddhistic spirituality) while embracing the "Absolute Truth" (Lotus Sutra). He also says that Kenji has his heart broken, non-unified, non-free and only had been beating, and Kenji's trajectory of faith was always accompanied by the conflict. And this conflict would become the base of Kenji's literature. In addition to that, he here introduces Kenji's world famous Memo Poem entitled "Ame nimo makezu (Unbeaten by Rain)" that the Kenji wrote in his last year [44] [45]. And he states that this one is a work which conveys the conflict truly between the two worlds (the "Existence of Savior" and the "Absolute Truth") through the behavior of Dekunobo (Jofukyobosatsu [常不軽菩薩]: Never Disparaging) appearing in this Poem. By the way, there are SDGs (Sustainable Development Goals; 17 Fields, 169 Items) in the UN Goal toward 2030. It is said in the 2030 Agenda that the Root of "Disparity" and "Poverty" is the "Environmental Destruction in Global scale" and the term "No one will be left behind" has been stated as the fundamental philosophy. We think that this phrase means a middle-of-the-roader's way of life in Buddhism. This is not a middle-ism which combines parts of two different things into a new thing, but also is not a compromise-ism which picks the best of both worlds. This would serve us the right way. So to use a metaphor, it could be said that this thought is something like a common attitude to the behavior of the Bodhisattva Never Disparaging.

By the way, the Key words extracted from the last page of "Ame ni mo Makezu” Techo are as follows. (1) Nichiren (日蓮), (2) Sado Island (佐渡島), (3) Jikkai Monji Mandara (十界文字曼茶羅), (4) Nam-myoho-renge-kyo (南無妙 
法蓮華経), (5) Namu Taho Nyorai (南無多宝如来), (6) Namu Shakamuni Nyobutsu (南無釈迦牟尼如仏), (7) Namu Jogyo Bosatsu (南無上行菩薩), (8) Namu Muhengyo Bosatsu (南無無辺行菩薩), (9) Namu Jyogyo Bosatsu (南無 浄行菩薩), (10 Namu Anryugyo Bosatsu (南無安立行菩薩). In these words, the four Bosatsu (Bodhisattvas: (7) Jogyo [上行], (8) Muhengyo [無辺行], (9) Jyogyo [浄行], (10) Anryugyo [安立行]) are in general called "Bodhisattvas of the Earth" in Buddhism. We think that the word "Bodhisattvas of the Earth" could be said as an identity for a citizen of the world. By the way, Japanese Famous Christian thinker Kanzo Uchimura (1861-1930) describes in his book that St. Nichiren is one (one person in the Buddhist priest) of the five representative men of Japan [46].

Figure 1 shows an example of the "Jikkai Monji Mandalas" that St. Nichiren has written many times since exile to Sado Island in Japan. It is said that he started to draw the Monji Mandala (Honzon: principal object of worship) at his age of fifty years old (1271) at the time exiled to Sado Island. And he had drawn the one hundred and twenty-seven Mandal as for about 10 years until death. In addition, it is said that this Mandala shows a Nichiren's view of nature [42]. And the handwriting part in the last page of "Amenimo Makezu techo" written by Miyazawa K. is that of “Itto-ryosonsisi (一塔両尊四士.)" This means 7 types of characters of central part of the series of "Monji-Mandala. (See Figure 2)" That is, Nam-myoho-renge-kyo (南無妙法蓮華経), Namu Taho Nyorai (南無多宝如 来), Namu Shakamuni Nyobutsu (南無釈迦牟尼如仏), Superior Practices (南無 上行菩薩), Infinite Practices (南無無辺行菩薩), Pure practices (南無浄行菩薩), and Firmly Established Practices (南無安立行菩薩) [44] [47] [48] [49] [50] [51].

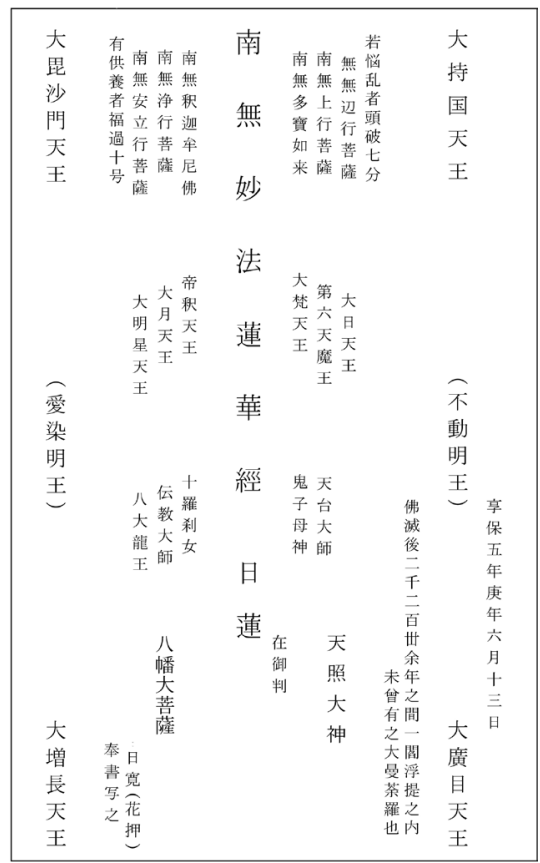

Figure 1. A Form Diagram of Jikkaigogu Monji-Mandala (Mutual Possession of the Ten Worlds Moji-Mandala) of St. Nichiren. 


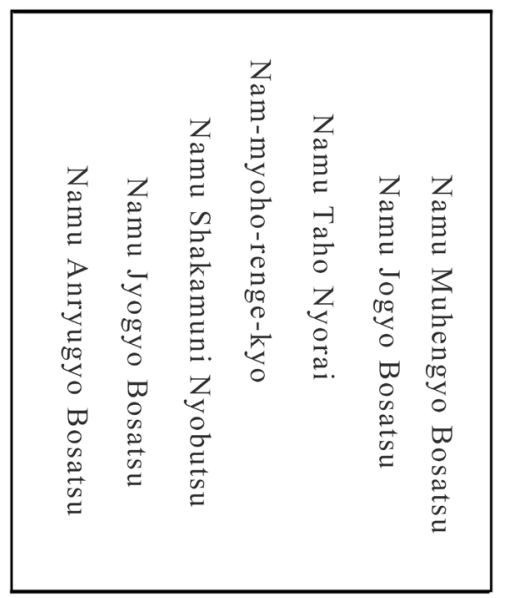

Figure 2. A Form Diagram of 7 types of characters of central part of the "Monji-Mandala" by Miyazawa K. (This is an image figure translated.)

This Mandala shows a form diagram of Jikkaigogu Monji-Mandala (Mutual possession of the ten worlds monji-mandala) of St. Nichiren. A Daimoku Hoto “南無妙法蓮華経” as the main portion is drawn in the center of it, and Shakamuni-nyobutsu and Taho-nyorai on the sides, with the four Bosatsu (Bodhisattvas: Jogyo [上行], Muhengyo [無辺行], Jyogyo [浄行], Anryugyo [安立行]) in the form of addition of both sides (Shakamuni-nyobutsu and Taho-nyorai). Incidentally, it is said that the four bodhisattvas are the leaders of the Bodhisattvas of the Earth.

In addition, Prof. Niwa introduces a form (schematic diagram) of the Monji-Mandala in the paper entitled" The doctrine behavior and outlook for the Buddhist temple of Nichiren [52] [53]." He states in his paper that this Mandala is one which was embodied based on the Kokue's view (Kokue [虚空会]: Ceremony in the Air. Koku (虚空) means one place in Nisho-sane [二処三会（霊山 - 虚空・霊山)]: Two places and three assemblies.

By the way, it is said that the point of the Lotus Sutra is in general as follows [54]. 1) 方便品第二 (Hoben-bon, Chapter 2 of the Lotus Sutra). This is a teaching scripture for all people to attain Buddhahood through 十如是 (Junyoze, Buddhism Ten Factors of Life) and 十界互具 (Jikkaigogu, Mutual Containment of the Ten Realms). But, even this is no more than a "Relative Happiness". 2) 如来 寿量品第十六 (Nyoraijuryo-bon, Chapter 16 of the Lotus Sutra). This is a teaching scripture (Dignity of Life) for all creatures including people that a Buddha who already earned enlightenment a very long time ago, in eternal past [It is called “Kuon jitsujo (久遠実成)”]. This means “Eternity of Life”. Therefore, we think that this is connected to "Absolute Happiness." Ru-Lev Nikolayevich Tolstoyis (A Greatest writer of the world-wide recognition) also expressed the" Eternity of Life" in his book [55].

In addition, Shakyamuni Buddha has the ten great disciples (迹化の菩薩: bodhisattvas of the theoretical teaching)such as Kashou (迦葉), Shariputra (舎利 弗), Maitreya Bodhisattva (弥勒菩薩) and Samantabhadra Bodhisattva (普賢菩 
薩) etc.) take over his mission (Handover after his death) but the "Bodhisattvas of the Earth (Innocent Live)" based on the "Eternity of Life" at the "Ceremony in the Air (Juji yujutsu hon, Chapter 15 of the Lotus Sutra").

By the way, "Sushun Tennō gosho (The Three Kinds of Treasure)" runs as follows regarding the essence of the training of Lotus Sutra [56]. The heart of the Buddha's lifetime of teachings is the Lotus Sutra, and the heart of the practice of the Lotus Sutra is found in the "Never Disparaging" chapter. What does Bodhisattva Never Disparaging's profound respect for people signify? The purpose of the appearance in this world of Shakyamuni Buddha, the lord of teachings, lies in his behavior as a human being.

It is stated in the passage that the heart of the practice of the Lotus Sutra lies in the "Never Disparaging" behavior as a human being. It is said that the poet and writer of children's stories Miyazawa K. loved deeply the" Bodhisattva Never Disparaging" saying an appearance of ascetic practices (the past life of Shakyamuni Buddha). St. Nichiren drew the Gohonzon of Ninpo-ikka (humans and law are melted into one [南無妙法蓮華経 日蓮]) with the Atsuhara-no-hōnan (Atsuhara Persecution: Oppression on the people), and he showed a practice method (Chanting First) with which the Nichiren believers are chanting the Nichiren chant (Nam-myoho-renge-kyo) to the Gohonzon. He showed the religion toward the world (all the people including all creatures) from Japan (Chanting the Nam-Myoho-renge-kyo which is a world-universal language in Japanese pronunciation with rhythmics $(116 \mathrm{~Hz})$ for "Rissho Ankoku (Construction of world peace)"). His idea is original, and we think that he is a global elite in the world. Figure 3 shows a monji mandara using frequency value as water quality. This was made after K. Miyazawa's Jikkai mandala.

Regarding the effect of the chanting, the Nichiren says in his writings that" It is the same with a Buddha and an ordinary being. When deluded, one is called an ordinary being, but when enlightened, one is called a Buddha. This is similar to a tarnished mirror that will shine like a jewel when polished. A mind now clouded by the illusions of the innate darkness of life is like a tarnished mirror, but when polished, it is sure to become like a clear mirror, reflecting the essential nature of phenomena and the true aspect of reality. Arouse deep faith, and diligently polish your mirror day and night. How should you polish it? Only by chanting Nam-myoho-renge-kyo [57]."

With respect to the mirror, it is said that although one's perspectives regarding the mirror image inversion seem to be at first glance a very simple problem, it has been a difficult problem which has rejected the challenge of a number of philosophers including Plato and physicists from more than 2000 years ago [58]. This means that it suggests the necessity of the mirror which reflects the one's world of life.

\subsection{Lotus Sutra as a Humankind's Universal Message}

We know a phrase from "Eastward advance" (Tōzen 東漸) to "Westward flow" 


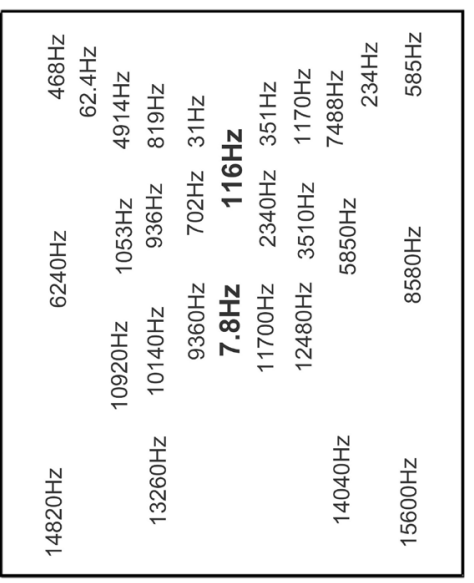

Figure 3. Monji mandara using frequency value as water quality. (This was made after K. Miyazawa’s Jikkai mandala.)

(Seikan 西還) in Buddhism (Buddha Buddhism (India) $\rightarrow$ Tendai Buddhism (China) $\rightarrow$ Nichiren Buddhism (Japan and the World). The very famous passage is stated in "Kangyo Hachiman-sho (On Reprimanding Hachiman)." A principle from “Eastward advance” (Tōzen 東漸) to “Westward flow” (Seikan 西還) in Buddhism is stated here. The passage is as follows. "The Land of the Moon is another name for India, the place where the Buddha made his appearance in the world. The Land of the Sun is another name for Japan. Is there any reason why a sage should not appear here? The moon moves from the west eastward, a sign of how the Buddhism of India spread in an easterly direction. The sun rises in the east, an auspicious sign of how the Buddhism of Japan is destined to return to the Land of the Moon. The light of the moon is not very bright, for the Buddha taught for only eight years of his life. But the light of the sun is brilliant, outshining the moon, an auspicious sign of how the Buddhism of Japan is destined to illuminate the long darkness of the fifthfive hundred-year period. The Buddha took no measures to correct those who slander the teachings of the Lotus Sutra, because while he was in the world there were no such persons. But in the Latter Day of the Law the formidable enemies of the single vehicle are everywhere in sight. Now is the time to benefit the world in the same manner as Bodhisattva Never Disparaging. You who are my disciples, each of you should work diligently at this, work diligently at this! [59]".

In this book, the last paragraph comes with the following passage. "In closing, the Daishonin states, 'The Land of the Moon is another name for India, the place where the Buddha made his appearance in the world. The Land of the Sun is another name for Japan. Is there any reason why a sage should not appear here? The moon moves from the west eastward, a sign of how the Buddhism of India spread in an easterly direction. The sun rises in the east, an auspicious sign of how the Buddhism of Japan is destined to return to the Land of the Moon.' Here he predicts the global spread of the 'Buddhism of the Sun,' the great pure Law of Nam-myoho-renge-kyo [59]." Incidentally, this is a prophetic "Gomon" (Nichi- 
ren Daishonin's letter for propagation) that the Buddhism teaching of Sunlight (Nichiren Buddhism in Japan) will spread to the world including India (the Buddha's Birthplace). This spread is called “Buppo Seikan (仏法西還)”. Dr. Ueki M. (Humanity) is a Japanese scholar in Buddhist studies [60]. He states the “Buppo Seikan (仏法西還)” introducing the Nichiren's writings such as (1) On the Buddha's Prophecy: Kenbutsu mirai ki (顕仏未来記) and (2) On the Five Guides for Propagation: Soya Nyudo dono moto Gosho (曽谷入道殿許御書) in this book. The English passages introduced for (1) and (2) are as follows.

(1) 'The Great Teacher Miao-lo says, "Does this not mean that Buddhism has been lost in India, the country of its origin, and must now be sought in the surrounding regions?" Thus, no Buddhism is found in India anymore. During the 150 years or so since barbarians from the north invaded the Eastern Capital in the time of Emperor Kao-tsung, both Buddhism and imperial authority became extinct in China. Concerning the collection of scriptures kept in China, not one Hinayana sutra remains, and most Mahayana sutras have also been lost. Even when Jakushō and other priests set out from Japan to take some sutras to China, no one was found there who could embrace these sutras and teach them to others. It was as though there were only wooden or stone statues garbed in priests' robes and carrying begging bowls. That is why Tsun-shih said, "It came first from the west, like the moon appearing. Now it is returning from the east, like the sun rising." These remarks make it clear that Buddhism is lost in both India and China.'

(2) 'During the two thousand years of the Former and Middle Days of the Law, the teachings flowed from the west to the east, like the evening moon that appears in the western sky. Now in the five hundred years of the Latter Day of the Law, they will move from the east to the west, like the morning sun coming up in the eastern sky.'

In addition, the passages mentioned above were quoted from the reference (Nichiren, S. (1272). In Gosho Translation Committee, Ed., the Writings of Nichiren Daishonin), 1, 401 and 2, 558, respectively.

\subsection{Rainwater Resource Management to Maintain the Sustainable Society Learned from Miyazawa Kenji's Worldview/View of Life ( $\fallingdotseq$ Logic of Encounter)}

We think that "Rainwater Fostering" is very important for sustainable water resource conservation in the world. Before considering this we briefly consider the two ways of thinking (1) Abidatsuma (higher teaching) [阿毘達磨] theory as a Buddhistic approach and (2) Big-bang theory as a scientific approach) to think about the "Rainwater Fostering." It is thought that (1) the former one teaches us that Nature/Universe occurs by Karman [業/宿命] which is invisible. On the other hand, it is explained that (2) the latter one teaches us the Nature/Universe originated sometime about 20 billion years ago from the cataclysmic explosion at extremely high density and temperature. 
By the way, St. Nichiren [日蓮] (1222-1282) showed that a calamity was not a natural disaster but a "man-made one." We could say that his approach is a Buddhistic one (Votary of the Lotus Sutra). Probably for that reason, he has received four times of great calamity in his lifetime. On the other hand, KAMO no Chomei [鴨長明] had written Hojoki (An Account of My Hut) at a hojo hermitage measuring about 9 square meters as a recluse. And he insisted a theory of "natural disaster" in his book. We could say that his approach is a Buddhistic one (Votary of the Vimalakirti Sutra viewed from T'ien-t'ai's Kyoso Hanjaku (evaluation of sutras) (Buddhist Doctrines known as "Fivefold Periods and Eight Teachings"). He fortunately never encountered such several great calamities in his lifetime compared with St. Nichiren. The one big difference between St. Nichiren [日蓮] (This-world oriented completely) and KAMO no Chomei [鴨長 明] (That-world oriented if anything) would be the presence or absence of the sufferings [61]. The Nichiren was a votary of the Lotus Sutra ("a man of action" who practices in the society of the real world.) He lived from the early Kamakura period through the mid One (1222-1282). However, there are definitely the great persecutions of the votaries by the person in authority in each era or society as is preached in the Lotus Sutra. The Nichiren received the four great persecutions (1) Attacked on Hermitage [39 years old], (2) Exiled to Izu Province [40 years old], (3) Attacked while on the move [43 years old], (4) Punishment of Beheading \& Exiled to Sado Island [50 years old) in his life time. Incidentally, he died at the age of 61 . So many people in general were discouraged and lost the power to live by the successive disasters and conflicts at that time. And the thought of "give up" (Giving up overcoming the difficulties by one's power) and the public tendency of "selfishness" (Wishing just one's own peace of mind) engulfed the society of the real world. The Nichiren states in his book entitled "Rissho Ankokuron (On Establishing the Correct Teaching for the Peace of the Land)" that he confronts the mind of "give up" which dominates their bases in the society at that time.

Under such circumstances, KAMO no Chomei [鴨長明] lived from the late Heian period through the early Kamakura (1155-1216). He wrote the Hojoki “(An Account of My Hut as a disaster book (personal history))”. In this book, he made Yuimakoji (維摩居士) of Yuimakyo (Vimalakirti Sutra) [維摩経] as a model of the way of life. Then it could be said that he was a votary of the Vimalakirti Sutra ("An unworldly person "who leaves the society of the real world.) Viewed from this perspective, it is understood that the way of life (Deeds) of KAMO no Chomei [鴨長明] made a great contrast to the Nichiren's. By the way, "Humanitarian Responsibilities" are very important as a Buddhistic approach.

Recently, the statements that the causes of the disaster is the artificial involvements are progressively coming out in the scientific approach, for example, 1) Human-caused climate change at a IPCC Fifth Assessment Report (2014) [62], 2) Human-induced large earthquake with producing the shale gas [63].

When considering this, the discussion for the theory of "Man-made disaster" 
will be fundamentally very important to prevent, suffice to say, the "Japan Sinks" and "World Sinks." Regarding this, Japanese distinguished scholar Prof. Fujii S. (Kyoto Univ.) introduces that St. Nichiren pointed out that the disaster was brought about by the messiness of the human's minds, and inquired the status of the country Japan through the "Rissho Ankokuron (On Establishing the Correct Teaching for the Peace of the Land)" based on the Lotus Sutra [64]. And, Prof. Emeritus, Murakai Y. (The Univ. of Tokyo) also proposes a word (1) "Korobanu saki no tsue (Prevention Is Better Than Cure.)" in this regard [65]. However, when it comes to the "theory of man-made disaster", "responsibility theory" that an administrative body has a horror of the measures will come out. This will also be an issue of the cost etc. from the viewpoint of the administration. Therefore, we think that a countermeasure of the attitude of (2) "Yosumi (Wait-and-See)" is very important at the same time. That is, we have no choice but have properly "Smart Power" with which we can use the attitude of both (1) "Korobanu saki no tsue" and (2) "Yosumi" facing up to the reality. Renowned philosopher Hans Jonas has published a book entitled "Sekinin toiu Genri: Kagaku-gijyutsu Bunmei no tameno Rinrigaku no Kokoromi (The imperative of responsibility: in search of ethics for the technological age)" as a statement of criticism to the science and technology on civilization in the form of his will in 1979 [65]. He states clearly in the book that the responsibility for the future lies with us in the present time. He uses a metaphor. That is, he compared the others in the future to an unweaned baby as a primitive and typical existence, and has created the beginning to a new theory of the responsibility in a direction from "legal responsibility for specific individual and group in the traditional ways of discussion" towards "humanitarian responsibility that are shared socially and collectively". We could say that this manifestation profession is exactly one of the pioneering ones regarding the theory of humanitarian responsibility. It is also considered that this could be connected with a mind of the "Rainwater Fostering." It can be said from a standpoint of water system that it would be exactly a process to delight in the rejoicing of one's own interests (the value "benefit of inconvenience") in the behavior (altruistic action process) of fostering the rainwater which is a source of water supply (Life). What is really valuable for people is just only an issue of "how to realize it" from the point of view of balance between "benefit of convenience" and "benefit of inconvenience." Japanese famous AI researcher Prof. Kawakami H. (Kyoto Univ.) proposes recently an idea called "Fubeneki to iu Hassou (an idea of 'benefit of inconvenience')" [66]. We think that the idea suggests that the realization to delight the new value for fostering the rainwater (inconvenience/troublesome) would be the most important thing (benefit) to prevent eternally the collapse of the water system. Here we show the two types of benefit for treating the wasted water in this regard. The one is a "Benefit of Inconvenience" Type (A) and the other is a" Benefit of Convenience" Type (B) as shown in Figure 4 and Figure 5 [67] [68]. By the way, the brief overview of the red rain in Sri Lanka is as follows. There was a red rain intermittently in Sri Lanka in 2012. And the microbial cells were found from the rain. 


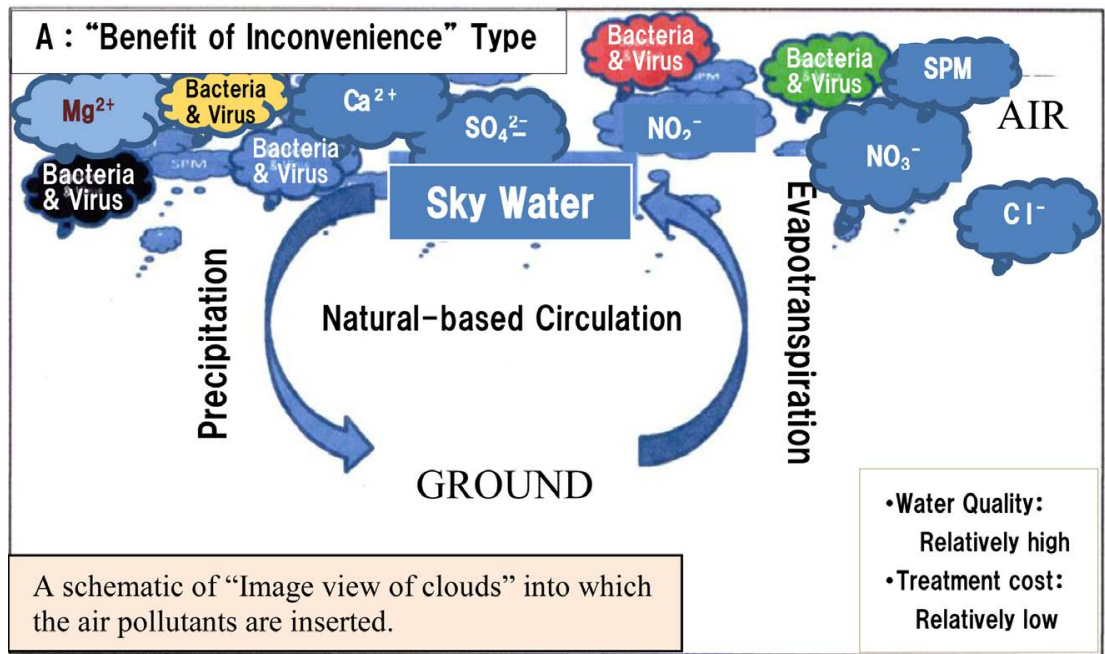

Figure 4. Schematic Image of Natural-based circulation of the sky water.

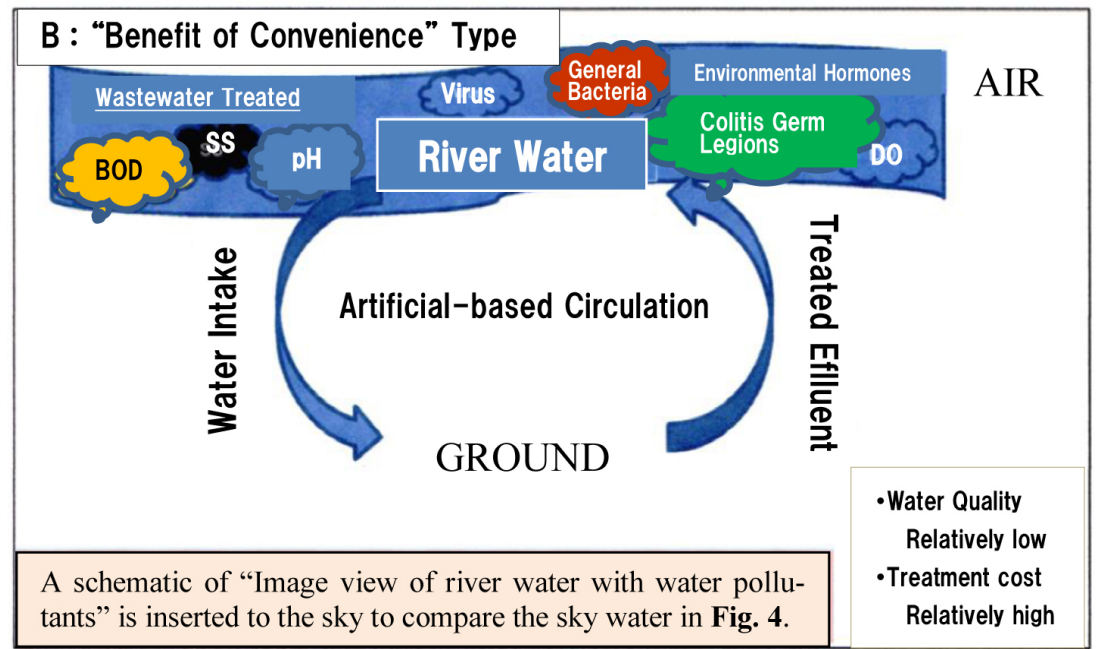

Figure 5. Schematic Image of Artificial-based circulation of the river water.

This book deals with the possibility of the microbial cells which live in the outer space (The Panspermia Theory: A Hypothesis on the Origin of Life). In connection with this mentioned above, it has been reported that an international team which consists of researchers from Japan, the United States, European countries has succeeded in capturing an image of a "Black Hole" for the first time in the world in early April (2019). With this success in photographing, it will spur the elucidation of "the origin of life." We think that one would realize the original purpose of the water [Distilled water] (1) Body temperature regulation \& (2) Body purification [waste clearance]) through the two types of the water circulation [69].

\section{An Experimental Study on Rainwater Quality Purification Based on the "Logic of Encounter"}

We understood that it is important to change the Karma (宿命転換) through the 
various kinds of principle of Buddhism mentioned above. Then we propose water quality purification based on the "Logic of Encounter" as a way to change the Karma (Rainwater Fostering [69]/Rainwater Rearing [70]) using a metaphor (comparing the rainwater to the life: purification of the rainwater by the sounds) in this paper.

\subsection{The Relationship between Sound and Rainwater Quality Purification Using Waterwheel Rotation}

Most part in this section is based on the content presented at the 13th International Symposium on Advanced Science and Technology in Experimental Mechanics held in Taiwan. Oct. 30-Nov. 2, 2018 [71].

\subsubsection{Experimental Procedures}

1) Waterwheel system and experimental condition

In this study, the standpoint is to understand how the basic drinking-water quality inspection items (Mandatory 11 items such as TOC, $\mathrm{NO}_{3}^{-} \& \mathrm{NO}_{2}^{-}$, $\mathrm{NO}_{2}^{-}$, General Bacteria, Colitis Germ legions, $\mathrm{pH}$, Chromaticity, Taste, Odor, Turbidity, $\mathrm{Cl}^{-}$) and two items related to the hardness such as $\mathrm{Ca}^{2+}, \mathrm{Mg}^{2+}$ of rainwater prescribed by the building administration law in Japan are cleaned in water supply by both (1) Lenard's Effect + Möbius Effect and (2) Ultrasonic Effect. The irradiation experiment was carried out using an ultrasonic cleaner at a frequency of $42 \mathrm{KHz}$ in this experiment. The irradiation time is as follows: 60 min. and $120 \mathrm{~min}$. (two phases). Regarding the measurement of the sound, the output direct sound which reaches someone's ears directly was used in this experiment. In this experiment, eight items such as TOC, $\mathrm{Ca}, \mathrm{Mg}, \mathrm{NO}_{3}^{-} \& \mathrm{NO}_{2}^{-}$, $\mathrm{NO}_{2}^{-}$, General Bacteria, Colitis Germ Legions, $\mathrm{pH}$ of all the 13 items were selected as the analytical ones. The commercially available waterwheel (Aqua Service. Co., Ltd. Fukuoka, Japan) was basically used in this experiment. EHEIM compact ON 300, made in Europe (Kamihata Co., Ltd., Hyogo, Japan) on the market is used as an underwater pump.

\section{2) Waterwheel system}

The waterwheel system used in this experiment is shown in Figure 6. We explore the possibility of rainwater quality purification by a simultaneous effect: (1) Production of negative ions $\fallingdotseq$ Lenard's Effect + (2) Rhythm of water rotation \& Vibration $\fallingdotseq$ Möbius Effect. At the bottom (two places; B1 \& B2/B3), the zinc plates were used as an acceleration material of waterfall effect. The specification of the waterwheel is shown in Table 1.

In addition, regarding 1) shown in Table 1, the rainwater was collected using the storage tank setup at home in Kyoto city. We here show a schematic image of water tank installed in each rooftop of building at Takao City, Taiwan (See Figure 7).

By the way, the sounds (frequencies) related to the rainwater purification have rhythm (including deviations). Regarding the rhythm, Emeritus Professor Yamazaki M. (Osaka University) says in his book entitled "Rizumu no Tetsugaku 


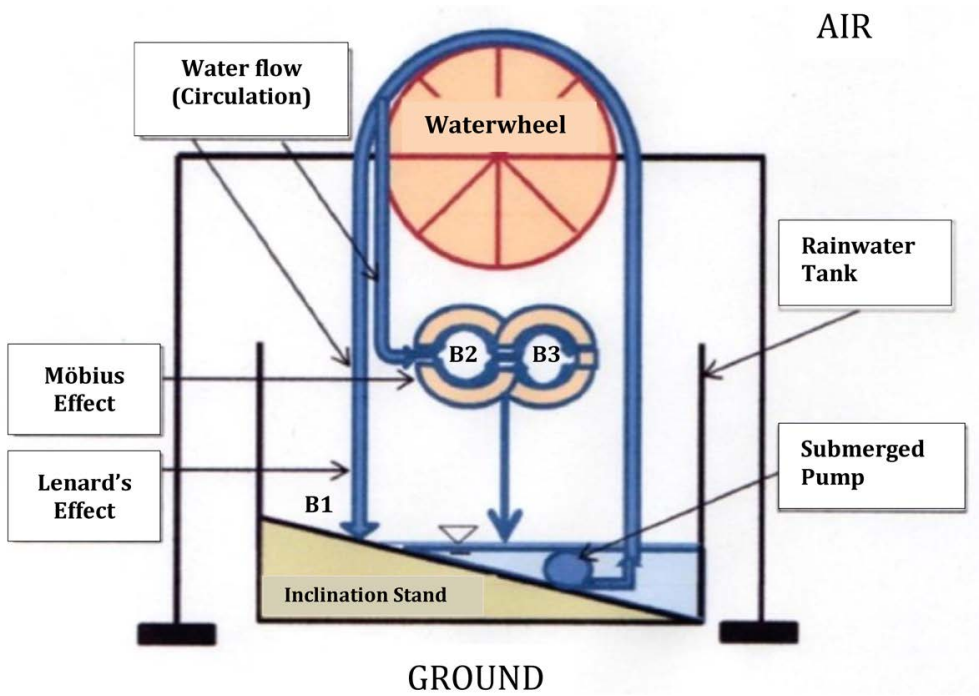

Figure 6. Schematic image of waterwheel used in this experiment.

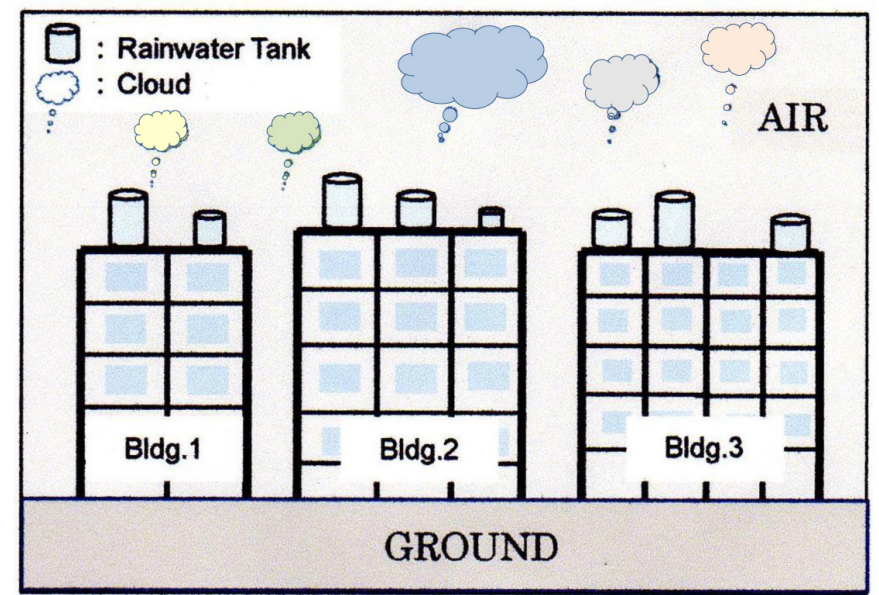

Figure 7. Schematic image of water tank installed in each rooftop of building at Kaohsiung city, Taiwan.

Table 1. Specification of the waterwheel.

1) Rainwater: sampled in June $19^{\text {th }}, 20^{\text {th }}$ and $23^{\text {rd }}$ in Kyoto city, Japan, 2018.

2)Number of rotations: $110 \mathrm{rpm}$

3)Diameter of rotations: $175 \mathrm{~mm}$

4) Height from the bottom to the center axis: $28.6 \mathrm{~cm}$.

5) Diameter of the axis: $7 \mathrm{~mm}$.

6) Mounting position: $156 \mathrm{~mm}$ from the bottom.

7) Width of the waterwheel: $40 \mathrm{~mm}$.

8) Wheel: 18 boxes (volume of each size: (W) $40 \times(\mathrm{H}) 25 \times$ (D) $27 \mathrm{~mm}$ ).

9) Flow rate :350 L/hr.

10) Dimensions of the unit: (H) $72 \times($ W) $38 \times(D) 62 \mathrm{~mm}$.

11) Water tank: $5 \mathrm{~L}$.

12) Temperature: $24^{\circ} \mathrm{C}$. 
Noto (Philosophy Notes of Rhythm)" that the accuracy caused by unconsciousness, the flow amplified by interruption and life to live by including death as seen in rhythm of the Universe, waxing and waning of the moon, waves on the sea, heart rate/respiration, rhythm of dancing and structure of the Shishi-odoshi (a traditional device found in Japanese gardens) have no choice but to say all of them paradoxically. However this paradoxical character is the very "essential" of the rhythm [72]. Therefore, it is thought that Shishi-odoshi will also be worthy of consideration for purifying the rainwater in the near future. The waterwheel in conjunction with the Shishi-odoshi is also a traditional device found in the countryside of Japan.

\section{3) Analytical Method of Water Quality}

The water quality analysis was conducted after the filtration using the filter named HARIO dripper which is available on the market. The testing methods for water quality analysis are as follows. ICP emission spectral analysis (JIS K 0101 49.3) for Ca, Mg, TOC meter (2003 MHLW Notification No. 261, appended table 30) for TOC, Ion chromatography (2003 MHLW Notification No. 261, appended table 13) for $\mathrm{NO}_{3}^{-} \& \mathrm{NO}_{2}^{-}$, Ion chromatography (2003 MHLW Notification No. 261, appended table 13) for $\mathrm{NO}_{2}^{-}$, and $\mathrm{pH}$ was conducted based on easy-to-use water quality test kit, made by Kyoritsu chemical-check lab., corp., Japan. And, standard agar medium method (2003 MHLW Notification No. 261, appended table 1) for General Bacteria, defined substrate method (2003 MHLW Notification No.261, appended table 2) for Colitis Germ Legions, respectively.

\subsubsection{Experimental Results and Discussion}

Figure 8 shows the analysis result of the frequency of the waterfall sounds (near the bottom 1 of the tank) brought about by the waterwheel. It is understood from this figure that the frequency of the sound covers a wide range of $20 \mathrm{~Hz}$ $15 \mathrm{KHz}$, and that its loudness is in a range of $-30 \mathrm{~dB}--80 \mathrm{~dB}$. The feature of the spectrum is that the spectrum of the peaks exists at the frequency near $25 \mathrm{~Hz}$, $130 \mathrm{~Hz}, 350 \mathrm{~Hz}, 1000 \mathrm{~Hz}, 4900 \mathrm{~Hz}$ and $7500 \mathrm{~Hz}$, respectively.

Figure 9 shows the analysis result of the frequency of the waterfall sounds (near the bottom 2 of the tank) and the range of the frequency is the same as that of its loudness in Figure 8. The feature of the spectrums is that the spectrum of the peaks exists at the frequency near $24 \mathrm{~Hz}, 40 \mathrm{~Hz}, 125 \mathrm{~Hz}, 280 \mathrm{~Hz}$ and $400 \mathrm{~Hz}$.

Figure 10 shows the analysis result of the frequency of the waterfall sounds (near the bottom 3 of the tank) and the range of the frequency is the same as that of its loudness in Figure 8. The feature of the spectrums is that the spectrum of the peaks exists at the frequency near $55 \mathrm{~Hz}, 150 \mathrm{~Hz}$ and $800 \mathrm{~Hz}$.

Table 2 shows the characteristics of the frequency spectrum measured at the bottoms (B1, B2/B3) of the tank. It is understood from the table that each fluctuation has its own individuality. In this experiment, the frequency regions and their fluctuations (deviations) can be roughly classified into one of three categories: low, middle and high ones and large, medium and small ones, respectively.

Table 3 shows an analysis result of the rainwater quality in this experiment. It 


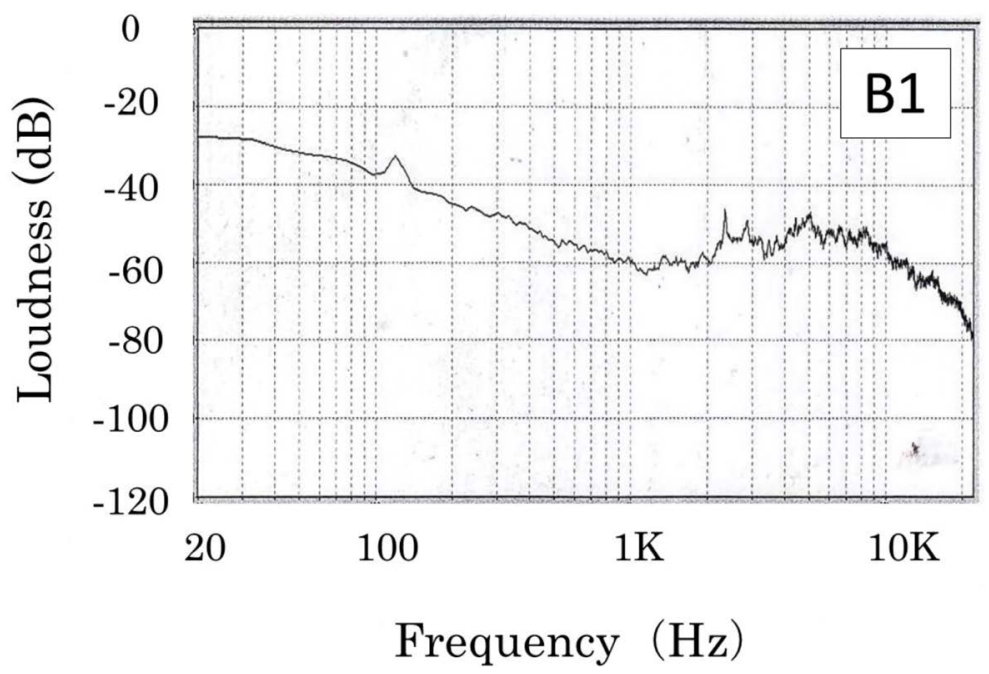

Figure 8. Analysis result of the frequency of waterwheel sound.

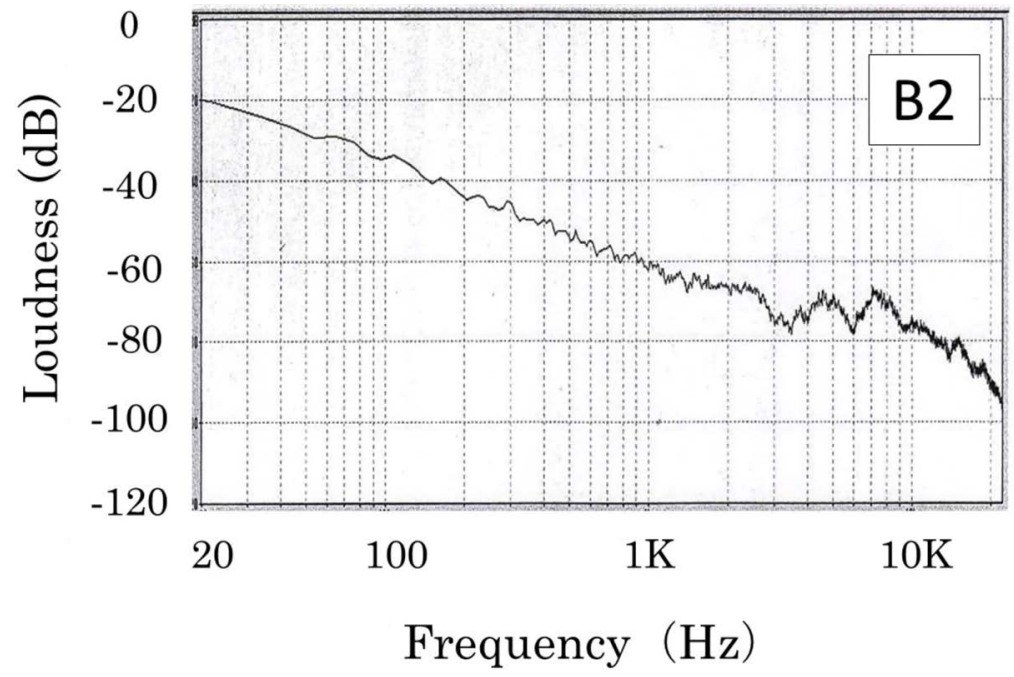

Figure 9. Analysis result of the frequency of waterwheel sound.

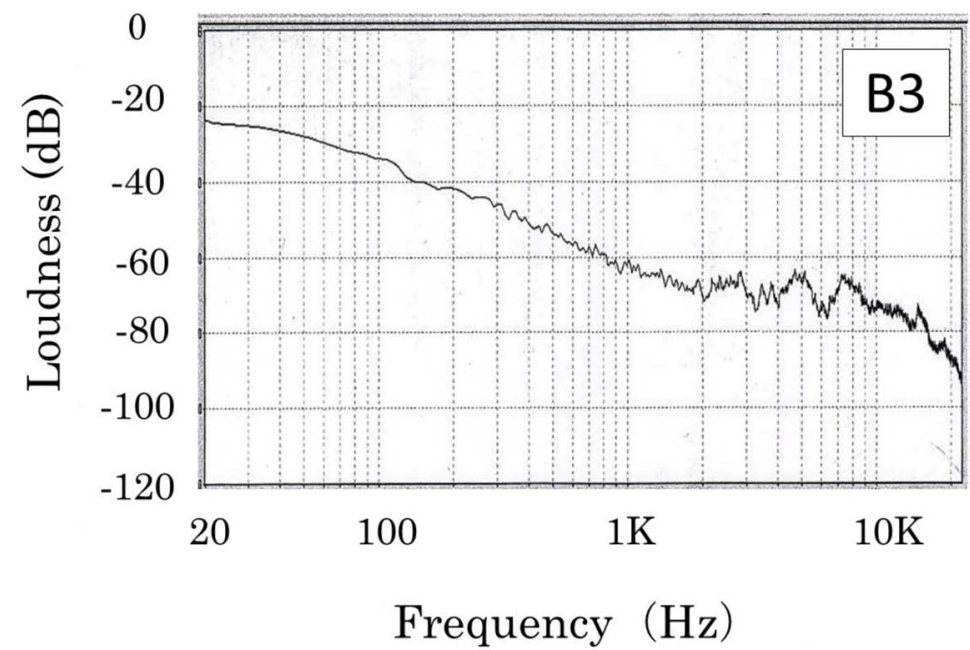

Figure 10. Analysis result of the frequency of waterwheel sound. 
Table 2. Summary table for the frequency spectrum.

\begin{tabular}{cccc}
\hline $\begin{array}{c}\text { Low } \\
\text { Frequency }(\mathrm{Hz})\end{array}$ & $\begin{array}{c}\text { Middle } \\
\text { Frequency }(\mathrm{Hz})\end{array}$ & $\begin{array}{c}\text { High } \\
\text { Frequency (Hz) }\end{array}$ & Remarks \\
\hline 25,130 & 350,1000 & 4900,7500 & Bottom 1 \\
(Fluctuation: Med.) & (Fluctuation: Small) & (Fluctuation: Large) & $(\mathrm{B} 1)$ \\
$24,40,125$ & 280,400 & - & Bottom 2 \\
(Fluctuation: Med.) & (Fluctuation: Med.) & & B2) \\
55,150 & 800 & - & Bottom 3 \\
(Fluctuation: Small) & (Fluctuation: Small) & & (B3) \\
\hline
\end{tabular}

Table 3. Analysis result of the rainwater quality.

\begin{tabular}{lcccc}
\hline $\begin{array}{c}\text { Elapsed } \\
\text { Time }\end{array}$ & $0 \mathrm{hr}$ & $1 \mathrm{hr}$ & $2 \mathrm{hrs}$ & $\begin{array}{c}\text { Drinking } \\
\text { Water Quality } \\
\text { Standards }\end{array}$ \\
$\begin{array}{l}\text { Water } \\
\text { Quality Items }\end{array}$ & 2.4 & 3.3 & 3.8 & $\leq 3 \mathrm{mg} / \mathrm{L}$ \\
\hline (1) $\mathrm{TOC}(\mathrm{mg} / \mathrm{L})$ & 400 & 450 & 440 & $\leq 300 \mathrm{mg} / \mathrm{L}$ \\
(2) $\mathrm{Ca}^{2+}(\mu \mathrm{g} / \mathrm{L})$ & 30 & 70 & 90 & $\leq 300 \mathrm{mg} / \mathrm{L}$ \\
(3) $\mathrm{Mg}^{2+}(\mu \mathrm{g} / \mathrm{L})$ & 0.3 & 0.3 & 0.3 & $\leq 10 \mathrm{mg} / \mathrm{L}$ \\
(4) $\mathrm{NO}_{3}^{-}$\& NO${ }_{2}^{-}(\mathrm{mg} / \mathrm{L})$ & 0.05 & 0.06 & 0.06 & $\leq 0.04 \mathrm{mg} / \mathrm{L}$ \\
(5) $\mathrm{NO}_{2}^{-}(\mathrm{mg} / \mathrm{L})$ & 13 & 9 & 8 & $\leq 100 \mathrm{CFU} / \mathrm{mL}$ \\
(6) $\mathrm{No}^{-}$of General Bacteria $(\mathrm{CFU} / \mathrm{mL})$ & $\mathrm{ND}$ & $\mathrm{ND}$ & $\mathrm{ND}$ \\
(7) $\mathrm{No}^{*}$ of Colitis Germ Legions & Detected & $\mathrm{ND}$ \\
(8) $\mathrm{pH}$ & 6.0 & 6.4 & 7.0 & $5.8-8.6$ \\
\hline
\end{tabular}

${ }^{\star}$ Not Detected.

is understood from this table that all the water quality items except TOC and $\mathrm{NO}_{2}^{-}$meet the drinking water quality standard (Building administration law) in Japan. Incidentally, the value of TOC has been severely changed from $\leq 5 \mathrm{mg} / \mathrm{L}$ to $\leq 3 \mathrm{mg} / \mathrm{L}$ (enforced in 2009, April 1st) nine years ago. We confirmed that there was a reduction effect (Detected $\rightarrow$ Not Detected) for General Bacteria and Colitis Germ Legions with the irradiation of the ultrasonic wave. Therefore, it is thought that the high frequency at bottom1 (B1@Figure 8) contributes to the reduction of the two bacteria, and that the middle and low frequencies at bottom 2 (B2@Figure 9) \& 3 (B3@Figure 10) contribute to the reduction of the other water qualities, respectively.

The TOC in the lower figure is showing a decreasing trend. And then, it was recognized that the TOC reached the required standard as a drinking-water.

Figure 11 shows the relation between the irradiation time of the sounds brought about by the waterwheel rotation and the rainwater quality; Total Organic Carbon (TOC). First of all, Total Organic Carbon (TOC) as general water quality items was checked. It was confirmed that the value of the TOC was slightly increasing from $0.9 \mathrm{mg} / \mathrm{L}$ for $1 \mathrm{hr}$. to $1.4 \mathrm{mg} / \mathrm{L}$ for $2 \mathrm{hrs}$, respectively. As described below (This means that the frequencies of the sounds (eight kinds: 24 $\mathrm{Hz}, 55 \mathrm{~Hz}, 130 \mathrm{~Hz}$ [Low frequency], $350 \mathrm{~Hz}, 800 \mathrm{~Hz}, 1000 \mathrm{~Hz}$ [Middle frequency], 


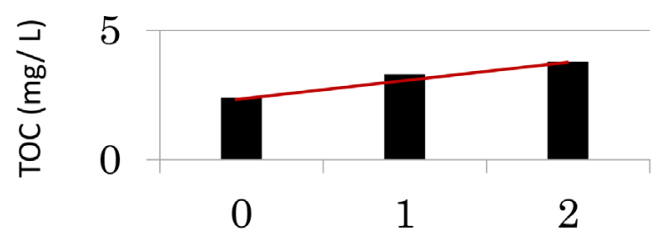

Irradiation time of waterwheel sound (hr)

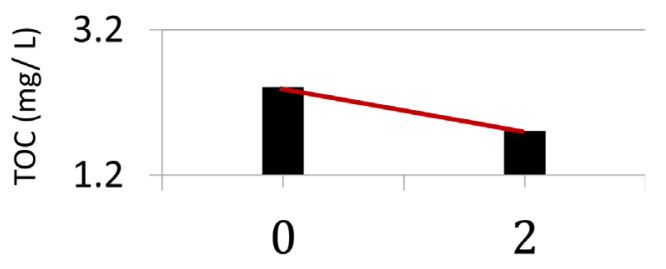

Irradiation time of waterwheel sound (hr)

Figure 11. Relation between the irradiation time of sound and TOC. (Upper is the case for the TOC obtained by the waterwheel rotation. And lower is the TOC obtained by the eight kinds of sounds brought about by the waterwheel rotation).

$4900 \mathrm{~Hz}$ and $7500 \mathrm{~Hz}$ [High frequency] obtained from the waterwheel in this experiment were selected and irradiated to the real rainwater for $2 \mathrm{hrs}$.), the reduction tendency of TOC $(2.4 \mathrm{mg} / \mathrm{L} \rightarrow 1.8 \mathrm{mg} / \mathrm{L})$ is particularly noticeable among water qualities in the irradiation experiment of the sound. This meets the drinking water quality standard, by the way. Viewed from this angle, the TOC reaches the required standard as a drinking-water (See Table 3). The 8 kinds of sounds, that is, $24 \mathrm{~Hz}, 55 \mathrm{~Hz}, 130 \mathrm{~Hz}$ [Low frequency], $350 \mathrm{~Hz}, 800 \mathrm{~Hz}, 1000 \mathrm{~Hz}$ [Middle frequency], $4900 \mathrm{~Hz}$ and $7500 \mathrm{~Hz}$ [High frequency] obtained from the waterwheel were applied to the rainwater. And then, it was recognized that TOC reached the required standard as a drinking-water (See Table 4).

Figure 12 shows the relation between the irradiation time of the sounds brought about by the waterwheel rotation and the rainwater quality; Calcium (Ca). Ca was also slightly increasing from $50 \mu \mathrm{g} / \mathrm{L}$ for $1 \mathrm{hr}$ to $40 \mu \mathrm{g} / \mathrm{L}$ for $2 \mathrm{hrs,}$ respectively. In this case, the $\mathrm{Ca}^{2+}$ reaches the required standard as a drinking-water (See Table 3).

Figure 13 shows the relation between the irradiation time of the sounds brought about by the waterwheel rotation and the rainwater quality; Magnesium (Mg). $\mathrm{Mg}$ was also increasing from $40 \mu \mathrm{g} / \mathrm{L}$ for $1 \mathrm{hr}$ to $60 \mu \mathrm{g} / \mathrm{L}$ for $2 \mathrm{hrs}$ compared with the 0 min. as well. In this case, the $\mathrm{Mg}^{2+}$ reaches the required standard as a drinking-water (See Table 3 ).

Figure 14 shows the relation between the irradiation time of the sounds brought about by the waterwheel rotation and the rainwater quality; $\mathrm{pH}$ value. $\mathrm{pH}$ gradually increased as the situation $(6.0 \rightarrow 6.4 \rightarrow 7.0)$ with the elapsed time of waterwheel sound. As the mean value of $\mathrm{pH}$ at Kyoto city (April, 2018) was 7 upper, this value could be said a welcome phenomenon. In this case, the $\mathrm{pH}$ reaches the required standard as a drinking-water (See Table 3).

Figure 15 shows the relation between the irradiation time of the sounds 


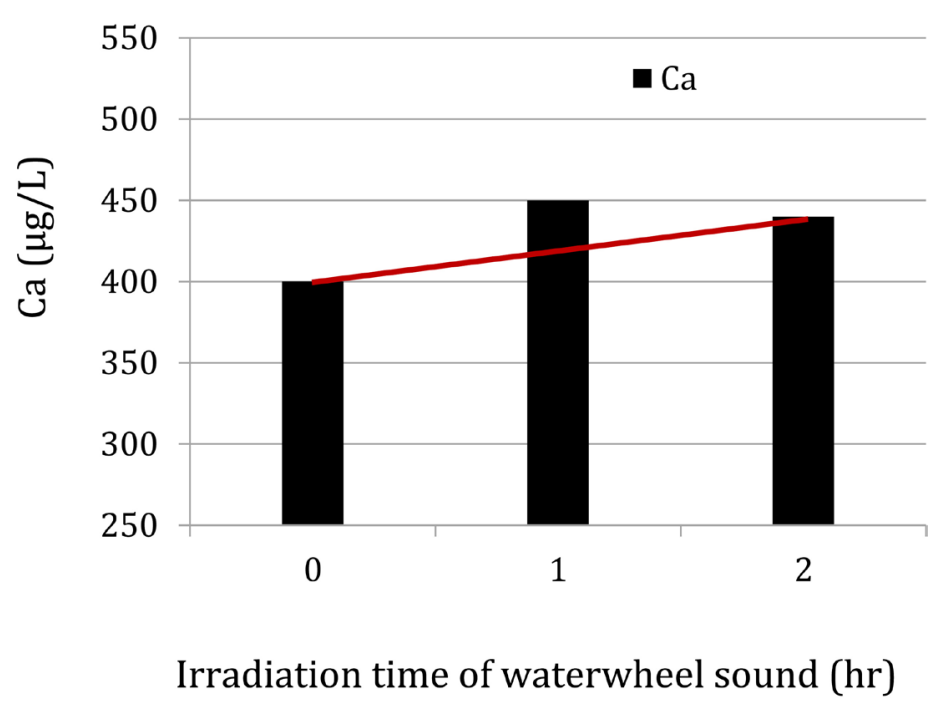

Figure 12. Relation between the irradiation time of sound and $\mathrm{Ca}$.

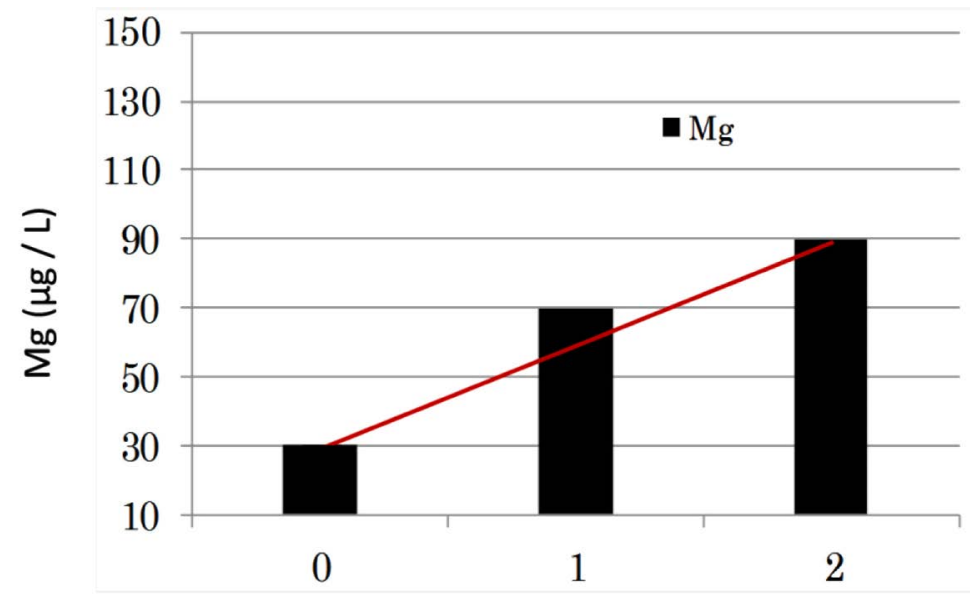

Irradiation time of waterwheel sound ( $\mathrm{hr}$ )

Figure 13. Relation between the irradiation time of sound and Mg.

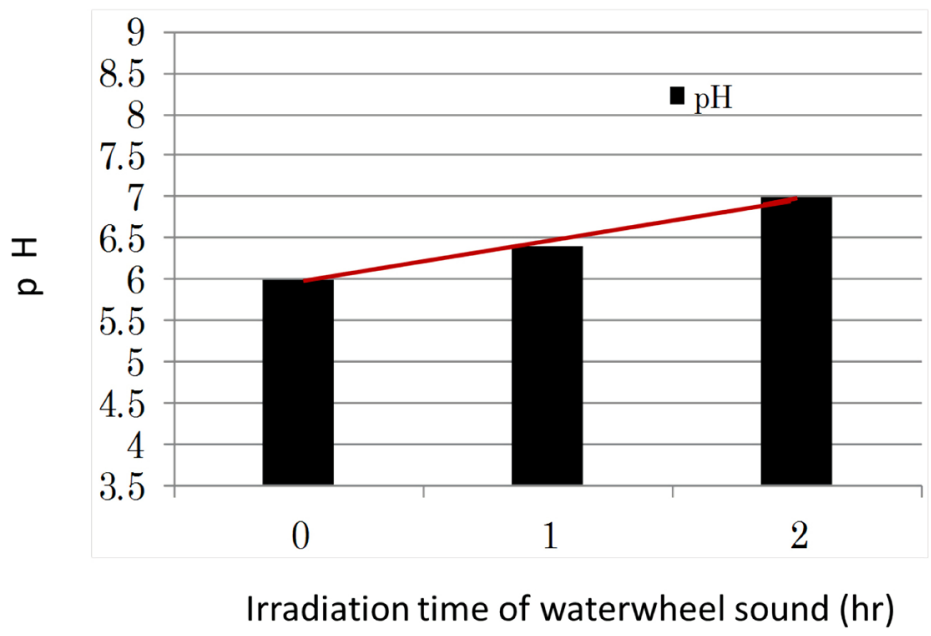

Figure 14. Relation between the irradiation time of sound and $\mathrm{pH}$. 


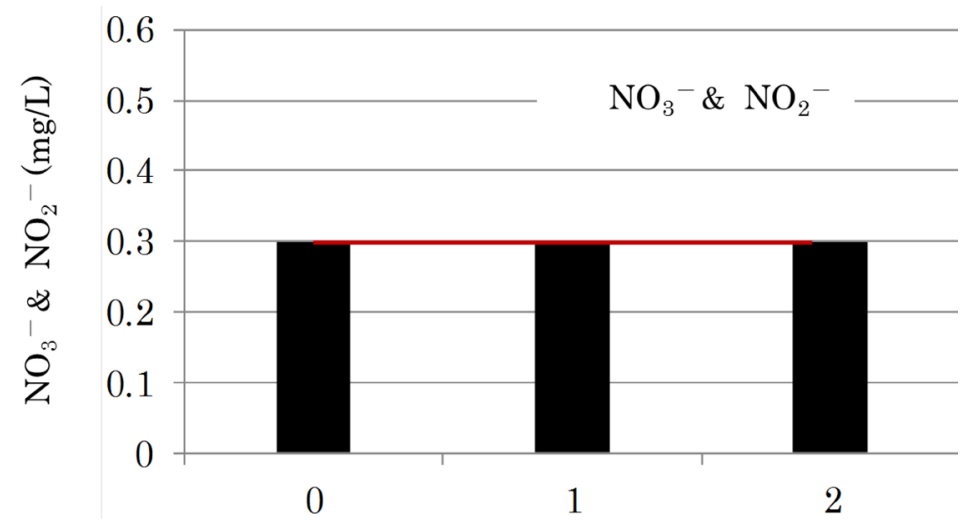

Figure 15. Relation between the irradiation time of sound and $\mathrm{NO}_{3}^{-} \& \mathrm{NO}_{2}^{-}$.

brought about by the waterwheel rotation and the rainwater quality; Nitrate and Nitrite Nitrogen $\left(\mathrm{NO}_{3}^{-} \& \mathrm{NO}_{2}^{-}\right)$as an atmospheric contaminant items included in the rainwater was checked. It was confirmed that the values of $\mathrm{NO}_{3}^{-} \& \mathrm{NO}_{2}^{-}$ did not change: $0.3 \mathrm{mg} / \mathrm{L}$ for $0 \mathrm{hr}, 1 \mathrm{hr}$, and $2 \mathrm{hrs}$ compared with the $0 \mathrm{~min}$. In this case, the $\mathrm{NO}_{3}^{-} \& \mathrm{NO}_{2}^{-}$reaches the required standard as a drinking-water (See Table 3).

Figure 16 shows the relation between the irradiation time of the sounds brought about by the waterwheel rotation and the rainwater quality; Nitrite $\mathrm{Ni}$ trogen $\left(\mathrm{NO}_{2}^{-}\right)$as an atmospheric contaminant item included in the rainwater was checked. It was confirmed that the values of $\mathrm{NO}_{2}^{-}$were slightly increasing by $0.01 \mathrm{mg} / \mathrm{L}$ for $1 \mathrm{hr}$ and also by $0.01 \mathrm{mg} / \mathrm{L}$ for $2 \mathrm{hrs}$ compared with the $0 \mathrm{~min}$. In this case, the $\mathrm{NO}_{2}^{-}$does not reach slightly the required standard as a drinking-water (See Table 3).

In general, it is said that $\mathrm{Ca}^{2+}, \mathrm{NO}_{3}^{-}, \mathrm{NO}_{2}^{-}, \mathrm{SO}_{4}{ }^{2-}, \mathrm{Cl}^{-}$and $\mathrm{SPM}$ are originally included in the rainwater as a sample water. $\mathrm{Ca}^{2+}$ and $\mathrm{Mg}^{2+}$ are neutralized with the sulfate $\left(\mathrm{SO}_{4}^{2-}\right)$ in the rainwater, and changed to Calcium sulfate $\left(\mathrm{SO}_{4}^{2-}\right)$ and Magnesium sulfate $\left(\mathrm{MgSO}_{4}\right)$, respectively. That is, the chemical reactions are probably as follows.

$$
\begin{aligned}
& \mathrm{Ca}^{2+}+\mathrm{SO}_{4}^{2-} \rightarrow \mathrm{CaSO}_{4} \\
& \mathrm{Mg}^{2+}+\mathrm{SO}_{4}^{2-} \rightarrow \mathrm{MgSO}_{4}
\end{aligned}
$$

The chemical reactions are the same as our previous paper entitled "Application of Ultrasonic Waves for the Improvement of Water Treatment" (Hiratsuka A. et al., Journal of WARP, 5, $604-610,2013$ ) [65]. From the above results of rainwater qualities, the increase of TOC, $\mathrm{Ca}^{2+}, \mathrm{Mg}^{2+}, \mathrm{pH}$ and $\mathrm{NO}_{2}^{-}$was confirmed. This estimates that these ions react to each other to make neutral chemical compounds. That is, following reactions occurred.

$$
\begin{aligned}
\mathrm{Ca}^{2+}+2 \mathrm{NO}_{3}^{-} & \rightarrow \mathrm{Ca}\left(\mathrm{NO}_{3}\right)_{2} \\
\mathrm{Mg}^{2+}+2 \mathrm{NO}_{3}^{-} & \rightarrow \mathrm{Mg}\left(\mathrm{NO}_{3}\right)_{2} \\
\mathrm{Ca}^{2+}+2 \mathrm{NO}_{2}^{-} & \rightarrow \mathrm{Ca}\left(\mathrm{NO}_{3}\right)_{2}
\end{aligned}
$$




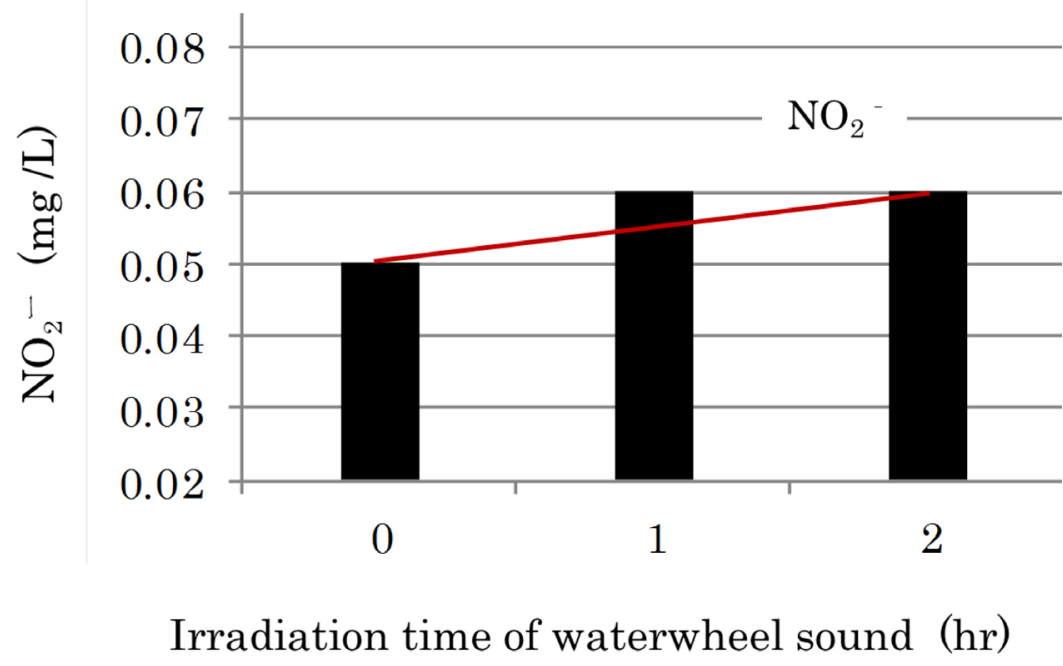

Figure 16. Relation between the irradiation time of sound and $\mathrm{NO}_{2}^{-}$.

$$
\mathrm{Mg}^{2+}+2 \mathrm{NO}_{2}^{-} \rightarrow \mathrm{Mg}\left(\mathrm{NO}_{3}\right)_{2}
$$

The chemical reactions are the same as our previous paper entitled "Improvement of Water and Wastewater Treatment Process Using Various Sound Waves" [73]. In addition, the $\mathrm{NO}_{3}^{-} \& \mathrm{NO}_{2}^{-}$also reaches the required standard as a drinking-water (See Table 3 ).

Figure 17 shows the relation between the irradiation time of the ultrasonic wave and the number of General Bacteria. As is seen from the figure, it is understood that the number of General Bacteria is reduced with the elapsed time of the irradiation of the ultrasonic wave. That is, the value was slightly decreasing by $4 \mathrm{CFU} / \mathrm{mL}$ for $1 \mathrm{hr}$ and by $5 \mathrm{CFU} / \mathrm{mL}$ for $2 \mathrm{hrs}$ compared with the $0 \mathrm{~min}$., respectively. (FYR; See our past paper [73])

We have examined the water quality purification using the ultrasonic waves for various kinds of the drinking-water so far. And then, in that paper, we recognized the bactericidal effect for General Bacteria. In this experiment, we have also confirmed the effect for General Bacteria. Next, the number of Colitis Germ Legions as bacteria item included in the rainwater was checked. Although the Colitis Germ Legions were detected in this sample rainwater itself, the value changed into ND after the irradiation for both $1 \mathrm{hr}$ and $2 \mathrm{hrs}$. As a result, the above two items (General Bacteria and Colitis Germ Legions) also reach the required standard as a drinking-water. (See Table 3) As is seen from the figure, it is understood that the number of General Bacteria is reduced with the elapsed time of the irradiation of the ultrasonic wave.

Next, the number of Colitis Germ Legions as bacteria item included in the rainwater was checked. Although the Colitis Germ Legions were detected in this sample rainwater itself, the value changed into ND after the irradiation for both $1 \mathrm{hr}$ and 2 hrs. As a result, the above two items (General Bacteria and Colitis Germ Legions) also reach the required standard as a drinking-water. (See Table 3) From the results mentioned above, it is understood that all the 6 rainwater 


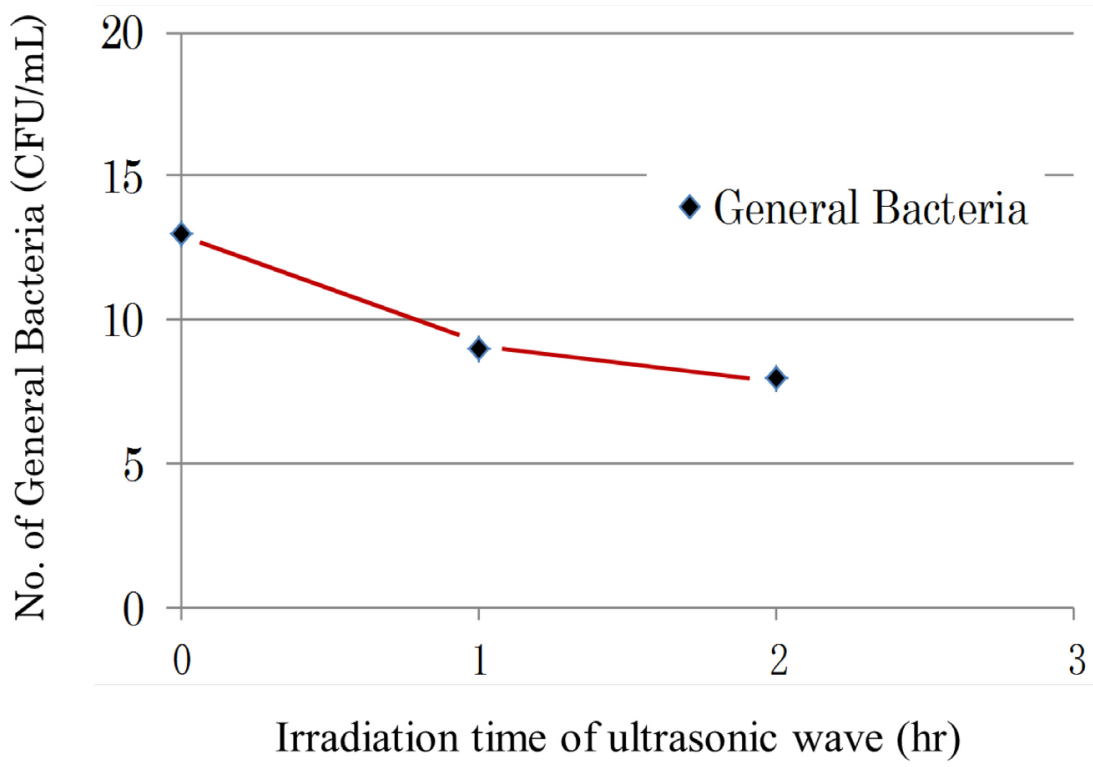

Figure 17. Relation between the number of General Bacteria and irradiation time of ultrasonic wave.

quality items such as $\mathrm{Ca}^{2+}$ (See Figure 12), $\mathrm{Mg}^{2+}$ (See Figure 13), $\mathrm{pH}$ (See Figure 14), $\mathrm{NO}_{3}^{-} \& \mathrm{NO}_{2}^{-}$(See Figure 15), the number of General Bacteria (See Figure 17) and the number of Colitis Germ Legions (See Table 3) except TOC (See Figure 11). (However, in case of the irradiation of the frequencies of the eight kinds of sounds obtained from the waterwheel rotation, the TOC met the standard.) and $\mathrm{NO}_{2}^{-}$(See Figure16) reach all the required standards as a drinking-water. Based on the above results, the frequencies of the sounds (eight kinds: $24 \mathrm{~Hz}, 55 \mathrm{~Hz}, 130 \mathrm{~Hz}$ [Low frequency], $350 \mathrm{~Hz}, 800 \mathrm{~Hz}, 1000 \mathrm{~Hz}$ [Middle frequency], $4900 \mathrm{~Hz}$ and $7500 \mathrm{~Hz}$ [High frequency] obtained from the waterwheel in this experiment were selected and irradiated to the real rainwater for $2 \mathrm{hrs}$. (See Figure18) Upon close examination, it is apparent to all of the frequencies that there are the harmonic overtones (Schumann Resonance) in this regard. As a result, the frequencies and irradiated time were selected as follows in the final experiment which is using a sound brought about by the waterwheel rotation.

Table 4 shows a table showing the value of the all water qualities using a sound brought about by the waterwheel rotation with the bracketed values obtained by irradiating the eight frequencies for two hours using the vibration speaker. As a result, it was seen in this experiment that the way by the eight frequencies shows a roughly similar tendency to the rainwater quality purification using a sound brought about by the waterwheel rotation. It means that only $\mathrm{NO}_{2}^{-}$(Nitrite nitrogen) needs to be confirmed in a further check by means of an other experiment. Therefore, we think that a possibility of a rainwater quality purification by the sound (eight frequencies) using a vibration speaker was suggested through the experiment.

In connection with the result mentioned above, it was figured out through all the waves under an entire frequency region (low, middle and high frequencies) 


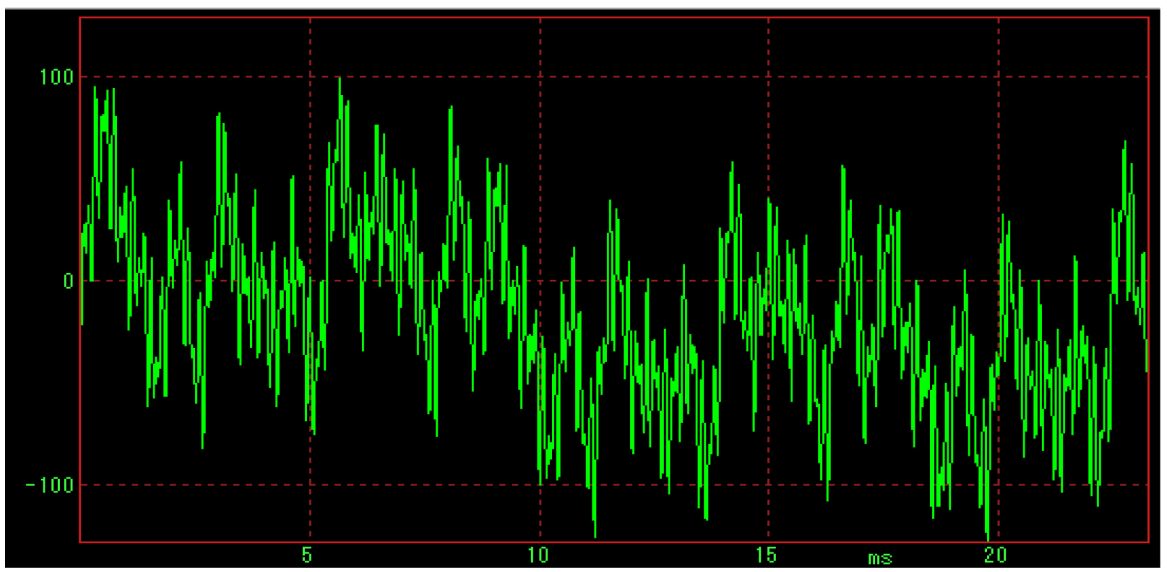

Figure 18. Waveform (eight kinds of frequencies irradiated).

Table 4. Result of water qualities obtained from the waterwheel rotation.

\begin{tabular}{|c|c|c|c|c|c|}
\hline $\begin{array}{l}\text { Water } \\
\text { Quality Items }\end{array}$ & $0 \mathrm{hr}$ & $1 \mathrm{hr}$ & $\begin{array}{l}2 \text { hrs ( ): by } \\
\text { sound }\end{array}$ & $\begin{array}{c}\text { Drinking } \\
\text { Water Quality } \\
\text { Standards }\end{array}$ & $\begin{array}{l}\text { Standard } \\
\text { decision }\end{array}$ \\
\hline (1) TOC (mg/L) & 2.4 & 3.3 & $3.8(1.8)$ & $\leq 3(\mathrm{mg} / \mathrm{L})$ & O \\
\hline (2) $\mathrm{Ca}^{2+}(\mu \mathrm{g} / \mathrm{L})$ & 400 & 450 & $440(290)$ & $\leq 300(\mathrm{mg} / \mathrm{L})$ & O \\
\hline (3) $\mathrm{Mg}^{2+}(\mu \mathrm{g} / \mathrm{L})$ & 30 & 70 & $90(30)$ & $\leq 300(\mathrm{mg} / \mathrm{L})$ & O \\
\hline (4) $\mathrm{NO}_{3}^{-} \& \mathrm{NO}_{2}^{-}(\mathrm{mg} / \mathrm{L})$ & 0.3 & 0.3 & $0.3(0.3)$ & $\leq 10(\mathrm{mg} / \mathrm{L})$ & O \\
\hline (5) $\mathrm{NO}_{2}^{-}(\mathrm{mg} / \mathrm{L})$ & 0.05 & 0.06 & $0.06(>0.05)$ & $\leq 0.04(\mathrm{mg} / \mathrm{L})$ & $\triangle$ \\
\hline $\begin{array}{l}\text { (6) No. of General Bacteria } \\
(\mathrm{CFU} / \mathrm{mL})\end{array}$ & 13 & 9 & $8(11)$ & $\leq 100(\mathrm{CFU} / \mathrm{mL})$ & O \\
\hline (7) No. of Colitis Germ Legions & Detected & ND & $\mathrm{ND}(\mathrm{ND})$ & $\mathrm{ND}^{*}$ & O \\
\hline (8) $\mathrm{pH}$ & 6.0 & 6.4 & $7.0(6.6)$ & $5.8-8.6$ & O \\
\hline
\end{tabular}

${ }^{\star}$ Not Detected.

that the $116 \mathrm{~Hz}$ (lowest resonance frequency) as an overtone of $7.8 \mathrm{~Hz}$ (Schumann frequency) seems to be a basic resonance frequency in audible range to purify the rainwater. So, we here conducted the next experiment using the eight frequencies $(7.8 \mathrm{~Hz}, 31 \mathrm{~Hz}, 116 \mathrm{~Hz}, 351 \mathrm{~Hz}, 819 \mathrm{~Hz}, 1170 \mathrm{~Hz}, 4914 \mathrm{~Hz}, 7488 \mathrm{~Hz})$ to purify especially the four rainwater qualities of $\mathrm{NO}_{2}^{-}, \mathrm{NO}_{3}^{-} \& \mathrm{NO}_{2}^{-}$, using the rainwater added an apple water (three percents in volume ratio) which seems to be a decreasing agent for nitrogen-based compounds.

By the way, the way of thinking of the decreasing method regarding $\mathrm{NO}_{2}^{-}$, $\mathrm{NO}_{3}^{-} \& \mathrm{NO}_{2}^{-}$, Number of General Bacteria, Number of Colitis Germ Legions is as follows. The principle of changing the $\mathrm{NO}_{2}^{-}$to $\mathrm{NO}_{3}^{-}$by using bacteria in the real rainwater (Decomposition of nitric acid-based component by bacteria) was utilized in this time. First, an apple water (Organic matter: //Sugar: $53 \mathrm{~g} / \mathrm{L}$, Galactooligosaccharide: $1.4 \mathrm{~g} / \mathrm{L}$, Carbohydrates: $53 \mathrm{~g} / \mathrm{L}$, Salt equivalent: 0 - 0.4 g/L, Energy: $210 \mathrm{Kcal} / \mathrm{L}$ ) was added into the rainwater. The volume ratio between the rainwater and the apple water is controlled to an optimal concentra- 
tion every time because of the dependence of the daily precipitation types. Here we tried to increase the bacteria in the rainwater and decrease the nitrogen-based components in the rainwater by the proliferated bacteria. At that time, the apple water with the organic matter was left to stand for 5 days at $20^{\circ} \mathrm{C}$ based on the BOD to check the decrease of the nitric acid-based component by bacteria.

Figure 19 \& Figure 20 show the result of the rainwater purification on $\mathrm{NO}_{3}^{-}$ \& $\mathrm{NO}_{2}^{-}$and $\mathrm{NO}_{2}^{-}$. It is understood from the figures that the each water quality item shows the purification effect, respectively. On the other, the Number of General Bacteria did not meet the standard. It is thought that the cause is the concentration of the apple water. (This time, the concentration was ten percent in volume ratio.) Here we show the result with standard decision of real rainwater qualities of adding the apple water (See Table 5). Of course viewing the outside of the audible range, it is thought that the bacterial killing by the ultrasonic

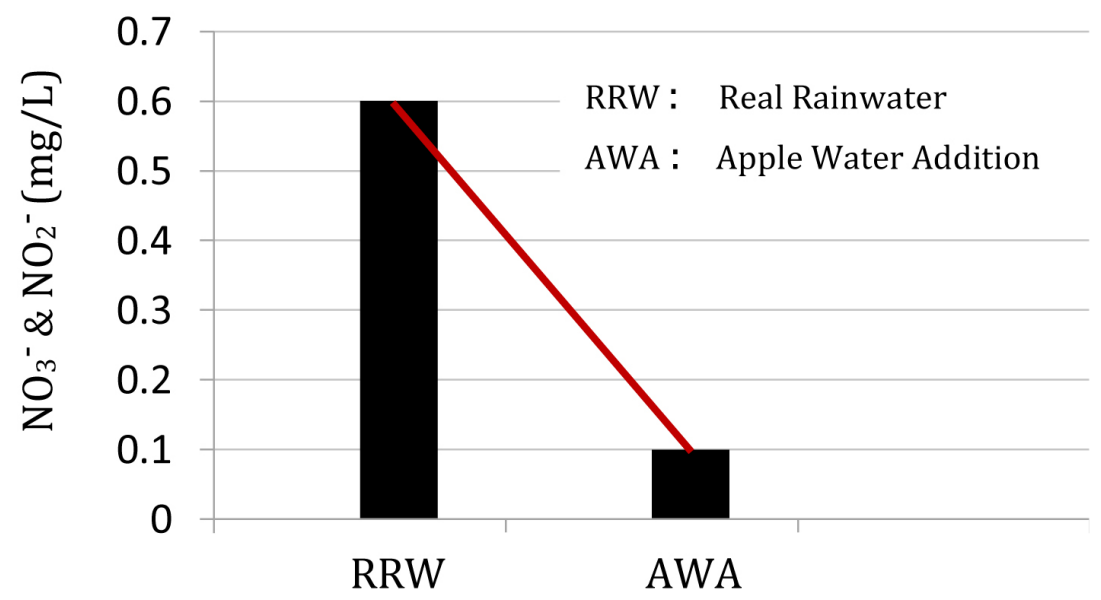

State of the water

Figure 19. Relation between the state of the water and $\mathrm{NO}_{3}^{-} \& \mathrm{NO}_{2}^{-}$.

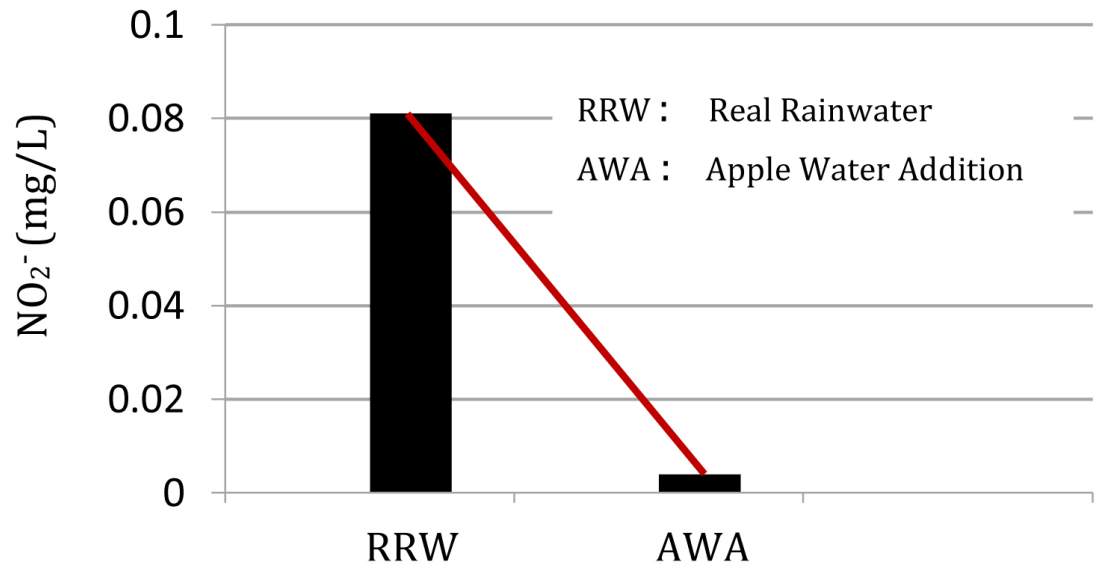

State of the water

Figure 20. Relation between the state of the water and $\mathrm{NO}_{2}^{-}$. 
Table 5. Result of real rainwater qualities of adding an apple water.

\begin{tabular}{|c|c|c|c|c|c|}
\hline $\begin{array}{l}\text { State of the water } \\
\text { Water } \\
\text { Quality Items }\end{array}$ & $\begin{array}{c}\text { Real } \\
\text { Rainwater } \\
(\mathrm{RRW})\end{array}$ & $\begin{array}{l}\text { Apple Water } \\
\text { Addition } \\
\text { (AWA) }\end{array}$ & $\begin{array}{l}\text { Water after } 2 \mathrm{hrs} \\
\text { Irradiation } \\
\text { (WAI) }\end{array}$ & $\begin{array}{c}\text { Drinking } \\
\text { Water Quality } \\
\text { Standards }\end{array}$ & $\begin{array}{l}\text { Standard } \\
\text { decision }\end{array}$ \\
\hline (4) $\mathrm{NO}_{3}^{-} \& \quad \mathrm{NO}_{2}^{-}(\mathrm{mg} / \mathrm{L})$ & 0.6 & $\leq 0.1$ & 0.2 & $\leq 10(\mathrm{mg} / \mathrm{L})$ & 0 \\
\hline (5) $\mathrm{NO}_{2}^{-}(\mathrm{mg} / \mathrm{L})$ & 0.08 & $\leq 0.004$ & $\leq 0.004$ & $\leq 0.04(\mathrm{mg} / \mathrm{L})$ & $\mathrm{O}$ \\
\hline $\begin{array}{l}\text { (6) No. of General Bacteria } \\
\text { (CFU/mL) }\end{array}$ & $>100$ & $>100$ & $>100$ & $\begin{array}{c}\leq 100 \\
(\mathrm{CFU} / \mathrm{mL})\end{array}$ & $x$ \\
\hline $\begin{array}{l}\text { (7) No. of Colitis Germ } \\
\text { Legions }\end{array}$ & ND & ND & ND & $\mathrm{ND}^{*}$ & $\mathrm{O}$ \\
\hline
\end{tabular}

${ }^{*}$ Not Detected.

waves is possible [74]. As is seen from the Table 4, only the number of general bacteria has not met the standard decision in this experiment.

Therefore, it is thought that the use of ultrasonic waves [73] or the boiling of the water [35] would be useful for the sterilization measures (sterilizing General Bacteria) at the conclusion of this case. Accordingly, this decreasing method regarding $\mathrm{NO}_{2}^{-}, \mathrm{NO}_{3}^{-} \& \mathrm{NO}_{2}^{-}$, General Bacteria, and Colitis Germ Legions must surely be good news for Asian countries such as Nepal, India and so on, where they have been now suffering from the groundwater contamination [75].

Incidentally, even the Bacteria are the members of the all creatures in the Buddhist view. So, it is important for us to face a purification with a way of thinking that "we kill the heart to kill." for the Bacteria (creatures). It could be said that this is a sustainable technique of rainwater purification method from now on in the future. This method is an appropriate way to purify the water quality with appreciating and handling the creatures.

By the way, it is thought that this way of thinking seems to have something in common on "Deep Ecology" that a World-famous Norwegian philosopher, Dr. Arne Næss (1912-2009) has advocated in 1973 [76]. In Japan, Eminent Buddhist scholar, Dr. Takemura M. has published a book entitled "Budhisuto EkorojiKyosei-Kankyo-Inochi (Buddhist Ecology-Harmonious co-existence-Environment-Life)" in 2016. And, we think that the thought of the treatment method mentioned above is also connected at their ways of thinking [77]. Incidentally, this is an artificial method for getting the drinking water of human beings by first reproducing the bacteria (creatures), and after that, killing them. The point we should be careful about is that the perception about killing the bacteria (creatures) is different in comparison with Dr. Naess' "Deep Ecology" (Radical Life-centricitism). Here, Buddha's Word "Korosu Kokoro wo Korosu (We kill the heart to kill)" would be a model of good behavior for the method of processing [78]. We think that this word is an excellent answer based on the view of “Engi (縁起)" on the basis of “Dignity of life." We receive that it emphasized the importance of the base way of thinking. That is to say that the one to exist deep in this word is that "Creatures" do not just only an objective subject of recognition. This one expresses the undifferentiated merciful state (the unifica- 
tion of objective and subjective phenomena) which is throbbing within the subjective life of human beings.

\section{Conclusions}

This paper mainly investigated the value of the rainwater by introducing a "Logic of Encounter" that is a new logic beyond the logos and lemma through the metaphors which compare the real rainwater to one's life. A consideration regarding sustainable rainwater resource utilization has been described in the paper. The main results are summarized as follows:

1) General Bacteria was almost wiped out by the ultrasonic wave irradiation for $2 \mathrm{hrs}$. Therefore, the effectiveness of the irradiation was confirmed for the disinfection of the real rainwater.

2) It is thought in changing the rainwater quality that there is a possibility relating to the simultaneous effect (Leonard's Effect and Möbius Effect) through the water quality purification process.

3) All of the rainwater qualities through the experiment were suggested to meet completely all of the required standards (Building Administration Law) in Japan as a drinking-water.

In addition, regarding the wiping-out of General Bacteria, an examinationconfirmation of the irradiation effects in the audible range $(20 \mathrm{~Hz}-20 \mathrm{KHz})$ could be pointed out in the near future.

\section{Acknowledgements}

In carrying out the study, Dr. IMAMURA Akitaka (Assoc. Professor, Osaka Sangyo University) supported us for doing the experiment, making the graph showing the frequency spectrum of the sound waves and so on. So we would like to express publicly here our deepest appreciation for his help and support. And we also would like to express sincere appreciation to Dr. TSUJINO Ryoji (Former Professor, Setsunan University) for checking the chemical reaction formulas. In addition, we would like to extend our appreciation to other relevant persons for their cooperation to complete the paper.

\section{Conflicts of Interest}

The authors declare no conflicts of interest regarding the publication of this paper.

\section{References}

[1] Crown Prince Naruhito (2019) Suiunshi kara Sekai no Mizu he (From History of Water Transportation to Water of the World-Speeches on Water Issues), NHK Shuppan. (In Japanese)

[2] http://www.kunaicho.go.jp/okotoba/02/okotoba/okotoba-h26az.html

[3] Nemoto, Y. (2011) Kuchiru Infura-Shinobiyoru Mouhitotsu no Kiki (The Rot in Infrastructure-Creeping Another Crisis). Nihon Keizai Shimbun Shuppansha, Tokyo. 
(In Japanese)

[4] Hiratsuka, A., Tomonaga, Y., Wakae, K. and Yasuda, Y. (2018) Study on Sustainable Water Resource Conservation-Toward Deepening of Homo Environmentics. Journal of Water Resource and Protection, 10, 327-368. https://doi.org/10.4236/jwarp.2018.103019

[5] Kioka, N. (2014) <Aida> wo Hiraku-Renma no Chihei (To Open the "Metaxu"-To Develop a Field of Lemma). Sekaishisosha, Kyoto. (In Japanese)

[6] Kiuchi, N. (2017) Kaikou no Ronri-<En> no Musubu Sekai he (Logic of En Couter-To the World Connected with En (“縁”: Relationship)). Shun Jyu-Sha, Tokyo. (In Japanese)

[7] Hiraoka, S. (2019) Namu Amida butsu to Namu myoho renge kyou (Amida Buddha and Nam-myoho-renge-kyo). Shinchosha. (In Japanese).

[8] Matsui, T. (2012) Ware Kakawaru Yueni Ware ari-Chikyu Shisutemu ron to Bunmei (I relate, therefore I am-Earth systems theory and civilization), 6, 220, Shueisha. (In Japanese)

[9] Morita, K. (2019) Naze Meikeieisha ha Ishida Baigan ni Manabunoka? (Why Do Great Managers Learn from Baigan Ishida?), Discover 21. (In Japanese)

[10] The Gosho in English, Bilingual Edition (Japanese and English) (2015) 147, Daisan Bunmeisha.

[11] Mori, M. and Kamide, H. (2018) Robotto Kougaku to Bukkyo-AI Jidai no Kagaku no Genkai to Kanousei (Robotics and Buddhism-Possibilities and Limits of Science in the Age of AI.). Kosei Shuppan, Tokyo. (In Japanese)

[12] Kamide, H. (2017) Practice of the Teaching of the Buddha for Robust Robots. JSPS Grants-in-Aid for Scientific Research, Grant-in-Aid for Challenging Exploratory Research (2015-2017).

[13] Joseph, S.N. (2011) The Future of Power, Public Affairs, USA.

[14] Ikegaya, Y. (2013) Tanjyun na Nou, Fukuzatsu na"Watashi” (Simple Brain, Complicated "Me"). Kodansha, Tokyo. (In Japanese)

[15] Oguri, H. (2013) Ooguri Sensei no Chogen Riron Nyumon (Prof. Oguri's Beginner's Guide to Superstring Theory). Kodansha, Tokyo. (In Japanese)

[16] Morita, M. (2015) Sugaku suru Shintai (Body Thinking Mathematics). Shinchosha, Yaraichō. (In Japanese)

[17] Norretranders, T. (2002) Yuza Iryujyon-Ishiki to iu Gensou (The User Illusion-Illusion Called “Consciousness.”) Translator: Shibata H., Kinokuniya Shoten, Tokyo. (In Japanese)

[18] Nakamura, H. (1980) Budda Saigo no Tabi-Dai Parinibbana Kyo (The Buddha's Last Journey-Mahāparinibbāna-suttanta). Iwanami shoten, Tokyo. (In Japanese)

[19] Stephen, T. (2018) Saishin Kagaku de Yomitoita Namu Myoho Renge Kyo (南無妙 法連華経: The Daimoku of the Lotus Sutra) (Nam-Myoho-Renge-Kyo Interpreted by the Latest Science). Being Net Press. (In Japanese)

[20] Stanley, O. (2001) Gendai Kagaku kara Buppo wo miru-Naze Inori ha Kanaunoka (Viewing the Teachings of Buddhism from Modern Science-Why Does Prayer Come True?) Daisan Bunmeisha, Tokyo. (In Japanese)

[21] https://www.nichirenlibrary.org/en/dic/Appendix/J

[22] Takemura, M. (2009) Nyumon / Tetsugaku to shite no Bukkyo (Introduction to Buddhism as a Philosophy). Kodansha, Tokyo. (In Japanese)

[23] http://d.hatena.ne.jp/santi 
[24] (2015) The Gosho in English, Bilingual Edition (Japanese and English). Daisan Bunmeisha, Tokyo, 12.

[25] Gasset, J.O. (1975) Donki Hote ni kansuru Shisaku (Speculation on Don Quixote). Anselmo Mataix/Sasaki T. (Joint Translation), Gendai Shichosha, Tokyo. (In Japanese)

[26] Nichiren, S. (1280) Issho Jyobutsusho (On Attaining Buddhahood in This Lifetime). Gosho Translation Committee, Ed., the Writings of Nichiren Daishonin, 1, 4.

[27] Sakurabe, H. and Ueyama, S. (1996) Sonzai no Bunseki “Abidaruma”-Bukkyo no Shiso 2 (Analysis of Existence "Meta-Teaching"-Thought of Buddhism 2). Kadokawa Shoten, Tokyo. (In Japanese)

[28] Sato, M., et al. (2018) Sekai no Erito ga ManandeiruTetsugaku·Shukyo no Jyugyo (The World's Elite have Learned "Lesson of Philosophy/Religion). PHP Institute. (In Japanese)

[29] Matsui, T. (2017) Bunmei ha <Mienai Sekai> ga tsukuru (Invisible World Makes the Civilization). Iwanami shoten, Tokyo. (In Japanese).

[30] Nishigaki, M., et al. (2013) Ikusui no Susume (Water Fostering) Gihodo shuppan. (In Japanese)

[31] Ishimure, M. (1969) Kugai Jyodo-Waga Minamatabyo (Paradise in the Sea of Sorrow: Our Minamata Disease). Kodansha, Tokyo. (In Japanese).

[32] Tatsuno, K. and Murase, M. (2004) Ame wo Ikasu-Tameru koto kara Hajimeru (Harvesting Rainwater-Let's Start to Accumulate Rainwater). Iwanami Shoten, Tokyo. (In Japanese)

[33] Exup'ery, A.S. (1955) Ningen no Tochi (Wind, Sand and Stars). Translator: Horiguchi, D., Shinchosha, Tokyo, 199. (In Japanese)

[34] Eliot, T.S. (1934) Choruses from the Rock. Cambridge University Press, Cambridge, 297-316.

[35] Sakaguchi, K. (2010) Zero kara hajimeru Toshigata Shuryo Saishu Seikatsu (An Urban Life Based on Hunting and Gathering Starting from Scratch.). Ohta Shuppan, Tokyo. (In Japanese)

[36] Fukuoka, S. (2014) Doteki Heikou Daiarogu-Sekai kanno Paradai mu Shifuto (Dynamic Equilibrium Dialogue-Paradigm Shift of World View). Kirakusha, Hikone. (In Japanese)

[37] Kimbrell, A. and Fukuoka, S. (Translator) (2017) Seimei ni Bubun ha nai (The Human Body Shop). Kodansha, Tokyo. (In Japanese)

[38] Stanley, O. (2001) Gendai Kagaku kara Buppo wo miru-Naze Inori ga Kanaunoka (Viewing the Teachings of Buddhism from Modern Science-Why Does Prayer Come True?) 31, 207, Daisan Bunmeisha, Tokyo. (In Japanese)

[39] Taguchi, Y. and Edahiro, J. (2018) Burenai Jiku wo tsukuru Toyo Shiso no Chikara (The Power of Oriental Thought That Makes a Stable Axis). Kobunsha, Tokyo. (In Japanese)

[40] Hiratsuka, A. (1996) Bunrisui no Suiryou-Suishitsu ni Chumoku shita GesuiOdei Koekibunri Sysutemu no Bunsekihyouka (Analysis and Evaluation of the Solid-Liquid Separation System of Sewage Sludge Focused on the Water Quantity and Water Quality of the Separated Water). Doctoral Dissertation, Osaka University, Osaka, 3-4. (In Japanese)

[41] Harari, Y.N. and Shibata, H. (Translator) (2018) Homo Deusu-Tekunoroji to Sapiensu no Mirai no Hazama de (Homo Deus: A Brief History of Tomorrow). Kawade Shobo Shinsha, Tokyo. (In Japanese) 
[42] Matsuoka, M. (2015) Miyazawa Kenji to Hokekyo-Nichiren to Shinran no Hazama de (Kenji Miyazawa and the Lotus Sutra-In between Nichiren and Shinran). Ronsosha, Tokyo. (In Japanese)

[43] Miyazawa, K. (2005) Ginga Tetsudo no Yoru (The Night of the Milky Way Train). Translated by Toyozaki, Y., and Varnam-Atkin, S., IBC Publishing, Tokyo. (In Japanese).

[44] Miyazawa, K. (1997) Shin-kohon/Miyazawa Kenji Zenshu13: Memo cho, Noto (New/the Complete Works of Miyazawa Kenji: Memorandum, Notebook/Body Portion). Vol. 13, Chikuma shobo, Tokyo. (In Japanese).

[45] http://www.pictio.co.jp/museum/work/361

[46] Uchimura, K. (2015) Daihyoteki Nihonjin (Representative Men of Japan). Bilingual Edition (Japanese and English), IBC Publishing, Tokyo.

[47] Watanabe, Y. (2007) Monji Mandara no Sekai-Nichiren no Shukyo (A World of the “Monji-Mandala”-St. Nichiren's Religion). Iwata Shoten, Tokyo. (In Japanese)

[48] Sunmark Publishing Inc. Editorial Department (1999) Miyazawa Kenji no Ikikata ni Manabu (Learn from Miyazawa Kenji's Way of Life). Sun Mark Publishing, Tokyo, 14-15. (In Japanese)

[49] Yamaori, T. (2005) Dekunobo ni Naritai-Watashi no Miyazawa Kenji (I Want to Be a Fool-My View of Kenji Miyazawa). Shogakukan, Tokyo. (In Japanese)

[50] Ueki, M. (2011) Bukkyo, Hontou no Oshie-Indo, Chugoku, Nihon no Rikai to Gokai (Buddism, the True Teachings-Understanding and Misunderstanding of India, China and Japan). Chuokoronshinsha, Tokyo, 216-219. (In Japanese).

[51] Yasuda, Y. (2008) Seimei Bunmei no Seiki he (To the Century of Life Civilization). Daisan Bunmeisha, Tokyo. (In Japanese).

[52] Niwa, H. (1984) Nihon Kenchiku Gakkai Ronbunshu (Transactions of the Architectural Institute of Japan). No. 343, p. 163. (In Japanese)

[53] Miyazawa, K. (1986) Miyazawa Kenji Zenshu 1 (The Complete Works of Miyazawa Kenji 1). Chikumashobo, Tokyo, 728-733. (In Japanese).

[54] Takahashi, I. (1987) Omamori Hokekyo (A Charm Myoho-renge-kyo). Toho Shuppan, Osaka. (In Japanese)

[55] Tolstoyis, R.N. (1958) Jinseiron (On Life). Translated by Kazuo, Y., Kadokawa Shoten, Tokyo. (In Japanese)

[56] Nichiren, S. (1280) The Three Kinds of Treasure. Gosho Translation Committee, Ed., the Writings of Nichiren Daishonin, Vol. 1, 851-852.

[57] Nichiren, S. (1255) On Attaining Buddhahood in This Lifetime. The Gosho in English, p. 21, 2015, Bilingual Edition (Japanese and English). Daisan Bunmeisha, Tokyo.

[58] Takano, Y. (2015) Kyoei Hanten-Kigenzen kara no Nanmon wo toku (Mirror Image Inversion-Solving Difficult Problems from More than 2,000 Years Ago). Iwanami shoten, Tokyo. (In Japanese)

[59] Nichiren, S. (1280) Kangyo-hachiman-sho (On Reprimanding Hachiman). Gosho Translation Committee, Ed., the Writings of Nichiren Daishonin, Vol. 2, 936, 938.

[60] Ueki, M. (2018) Edo no Dai Shijin Gensei Shonin-Kyoto Fukakusa de Hagukunda Shishin to Bukkyo. (A great poet in Edo era Gensei Shonin (元政上人)—Poetic sentiment and Buddhism born in Fukakusa, Kyoto.) Chuo Koron Shinsha. (In Japanese)

[61] Kobayashi, K. (2013) Kamo no Chomei Hojoki (鴨長明 An Account of My Hut as 
a Disaster Book (Personal History)). NHK Shuppan, Tokyo. (In Japanese)

[62] Japan Environment Agency (2014) The Summary of the IPCC Fifth Assessment Report.

https://www.env.go.jp/earth/ipcc/5th/pdf/ar5_wg1_overview_presentation.pdf

[63] Shimamura, H. (2008) Jishinyochi ha Uso darake (Earthquake Predictions Are Full of Lies). Kodansha, Tokyo. (In Japanese).

[64] Fujii, S. (2019) Hyogensha Criterion (Creator Criterion), a Special Edition 1: "Shiso" to Shiteno Bosai (Disaster Prevention as a Thought). Keibunsha shobo, Tokyo. (In Japanese)

[65] Jonas, H. (2000) Sekinin to iu Genri: Kagakugijyutsu Bunmei no tameno Rinrigaku no Kokoromi (The Imperative of Responsibility: In Search of Ethics for the Technological Age). Translator: Kato, H., Toshindo. (In Japanese).

[66] Kawakami, H. (2017) Gomennasai Moshi Anata ga Chotto demo Ikizumari wo Kanjite irunara Fuben wo Toriirete miteha Doudesuka?-Fubeneki to iu Hassou (Sorry, If You Feel a Little Bit a Deadlock in Your Life, Why Do Not You Try to Adopt the Inconvenience?-An Idea of Benefit of Inconvenience). Impress, Tokyo. (In Japanese)

[67] Matsui, T. (2013) Suriranka no Akai Ame-Seimei ha Uchuu kara Hiraisuruka (Red Rain in Sri Lanka-Does Life Find in Outer Space?) Kadokawa Gakugei Shuppan, Tokyo. (In Japanese)

[68] Landone, B. (1994) Body Purification-A Course of 13 Lessons, Health Research Books, Pomeroy, Washington, USA.

[69] Nishigaki, M., et al. (2013) Ikusui no Susume-Chikasui no Riyou to Hozen (Water Fostering-Utilization and Conservation of the Groundwater). Gihodo shuppan, Tokyo. (In Japanese).

[70] Serizawa, S. (2018) Serizawa Shunsuke Youiku wo Kataru (Serizawa Shunsuke Describes His Own Experience on Rearing). Opcode Institute Publisher. (In Japanese).

[71] Hiratsuka, A., Tomonaga, Y., Imamura, A. and Tsujino, R. (2018) The Relationship between Sound and Rainwater Quality Purification Using Waterwheel Rotation. 13th International Symposium on Advanced Science and Technology in Experimental Mechanics, Kaohsiung City, 30 October-2 November 2018.

[72] Yamazaki, M. (2018) Rizumu no Tetsugaku Nouto (Philosophy Notes of Rhythm). Chuokoron Shinsha. (In Japanese)

[73] Hiratsuka, A. and Pathak, D.R. (2013) Application of Ultrasonic Waves for the Improvement of Water Treatment. Journal of Water Resource and Protection, 5, 604-610.

[74] Hiratsuka, A., Tomonaga, Y., Yasuda, Y. and Tsujino, R. (2014) Improvement of Water and Wastewater Treatment Process Using Various Sound Waves-A Consideration from the Viewpoint of Frequency. Journal of Water Resource and Protection, 6, 1464-1474.

[75] Pathak, D.R., Hiratsuka, A. and Yamashiki, Y. (2011) Current Status and Trend of Nitrate-N and Factors Affecting Its Concentration in Shallow Groundwater Systems of Kathmandu. World Environmental and Water Resources Congress, 22-26 May 2011, Volume 414, 102.

[76] Næss, A. (1989) Ecology, Community and Lifestyle: Outline of an Ecosophy. Cambridge University Press, Cambridge.

[77] Takemura, M. (2016) Budhisuto Ecoroji-Kyosei-Kankyo-Inochi no Shiso (Budd- 
hist Ecology-Co-Existence Environment Thought of Life). Nonburusha, Hachiōji. (In Japanese)

[78] Buddha, Nakamura H. (Translator) (1958) Budda no Kotoba-Sutta-nipata (Buddha's Words: Sutta Nipata). Iwanami Shoten, Tokyo. (In Japanese) 